\title{
Plasma Rich in Growth Factors in the Treatment of Endodontic Periapical Lesions in Adult Patients: A Narrative Review
}

\author{
Agata Zoltowska $^{1}(\mathbb{D})$ Katarzyna Machut ${ }^{1}\left(\mathbb{D}\right.$, Elzbieta Pawlowska $^{2}(\mathbb{D})$ and Marcin Derwich $^{3, *(D)}$ \\ 1 Department of Endodontic Dentistry, Faculty of Medicine, Medical University of Gdansk, \\ 80-210 Gdansk, Poland; azol@@gumed.edu.pl (A.Z.); katarzyna.machut@gumed.edu.pl (K.M.) \\ 2 Department of Orthodontics, Medical University of Lodz, 90-419 Lodz, Poland; \\ elzbieta.pawlowska@umed.lodz.pl \\ 3 ORTODENT, Specialist Orthodontic Private Practice in Grudziadz, 86-300 Grudziadz, Poland \\ * Correspondence: derwichm@tlen.pl; Tel.: +48-660-723-164
}

Citation: Zoltowska, A.; Machut, K.; Pawlowska, E.; Derwich, M. Plasma Rich in Growth Factors in the Treatment of Endodontic Periapical Lesions in Adult Patients: A Narrative Review. Pharmaceuticals 2021, 14, 1041. https://doi.org/ $10.3390 /$ ph14101041

Academic Editor: Bin Duan

Received: 30 September 2021 Accepted: 12 October 2021 Published: 13 October 2021

Publisher's Note: MDPI stays neutral with regard to jurisdictional claims in published maps and institutional affiliations.

Copyright: (c) 2021 by the authors. Licensee MDPI, Basel, Switzerland. This article is an open access article distributed under the terms and conditions of the Creative Commons Attribution (CC BY) license (https:// creativecommons.org/licenses/by/ $4.0 /)$.

\begin{abstract}
Platelet concentrates have been widely used in regenerative medicine, including endodontics. The aim of this manuscript was to assess critically the efficacy of PRF in the treatment of endodontic periapical lesions in adult patients on the basis of the literature. The PICO approach was used to properly develop literature search strategies. The PubMed database was analyzed with the keywords: “((PRP) OR (PRF) OR (PRGF) OR (CGF)) AND (endodontic) AND ((treatment) OR (therapy))". After screening of 155 results, 14 articles were included in this review. Different types of platelet concentrates are able to stimulate the processes of proliferation and differentiation of mesenchymal stem cells. Platelet rich fibrin (PRF) releases growth factors for at least 7 days at the application site. Growth factors and released cytokines stimulate the activity of osteoblasts. Moreover, the release of growth factors accelerates tissue regeneration by increasing the migration of fibroblasts. It was not possible to assess the efficacy of PRF supplementation in the treatment of endodontic periapical lesions in permanent, mature teeth with closed apexes, due to the lack of well-designed scientific research. Further studies are needed to analyze the effect of PRF on the healing processes in the periapical region.
\end{abstract}

Keywords: plasma rich in growth factors; platelet rich fibrin; advanced platelet rich fibrin; apical periodontitis; endodontics; endodontic treatment; bone regeneration

\section{Introduction}

The term "periapical periodontium" encompasses all of the periradicular tissues localized in the area of the apex of the root, including periodontal ligaments, cementum and alveolar bone. Periapical periodontium is a part of the tooth suspension apparatus [1]. Apical periodontitis is the inflammatory process localized within the periapical periodontium, which is known as the host defense to the invasive microflora localized in the root canal system [2,3]. Nair describes the apical periodontitis as a dynamic encounter between root canal infection and host response [3]. There have been listed several different etiological factors which may cause the periapical periodontitis, namely: pulp pathology (infection, necrosis), tooth trauma, and also chemical, mechanical and bacterial factors related to the performed endodontic treatment (also known as root canal treatment) [2-8].

The onset of the inflammation within the periapical tissues depends on the time, the type of the pathological stimulus, and the susceptibility of the tissues [9]. Inflamed periapical tissues are considered to be free from bacteria [7]. However, there have also been published some studies, which confirm the presence of the bacteria biofilms on the root surfaces outside of the apical foramen. Noguchi et al. [10] detected Fusobacterium nucleatum (in all samples), Porphyromonas gingivalis (in 12 of 14 cases) and Tannellera forsythensis (in 8 of 14 samples) within the periradicular biofilms taken from the patients diagnosed with the resistant periapical periodontitis. 
There are a few different treatment methods of chronic periradicular inflammatory processes, including root canal treatment (RCT), combination of conservative and surgical treatment (endodontic microsurgery), and sometimes, in non-prognostic cases-tooth extraction [4,8,11-14]. Moreover, some authors also recommend combination of abovementioned methods of treatment with the physical therapy (biostimulation with laser therapy, iontophoresis, induction of low magnetic field, i.e., magnetostimulation). In authors' opinions additional physical therapy improves the effectiveness of a basic treatment and intensifies the regeneration processes and repairs [15-18].

Autologous platelets concentrate (APC) can be additionally used in the endodontic and surgical treatment, as well as after tooth extraction. APC has been found to be a biomaterial with a proven regeneration and repair improvement effect $[19,20]$. Platelets affect the process of angiogenesis by releasing growth factors from alpha-granules. The exemplary growth factors released form platelets alpha-granules are platelet-derived epidermal growth factor (PD-EGF), platelet-derived growth factor (PDGF), vascular endothelial growth factor (VEGF), basic fibroblast growth factor (bFGF) and transforming growth factor-beta (TGF- $\beta$ ) [21-23].

There can be obtained various types of APC, depending on the exact method of centrifugation. Platelet rich plasma (PRP) is an exemplary type of APC, which is formed by mixing platelet concentrate, derived from the centrifugation of autologous whole blood, with thrombin and calcium chloride [24]. Contrary to PRP, to obtain platelet rich fibrin (PRF) no additional anticoagulants are needed. Apart from platelets, PRF contains many blood cells, including B and T lymphocytes, monocytes, neutrophils, stem cells, as well as growth factors [25].

So far, PRF has been widely discussed in the field of oral surgery and pediatric dentistry. However, very little is known about the efficacy of PRF in the treatment of periapical lesions in mature, permanent teeth with closed apexes. Therefore, the aim of this manuscript was to assess critically the efficacy of PRF in the treatment of endodontic periapical lesions in adult patients on the basis of the literature.

\section{Molecular Background of the Endodontic Periapical Lesions}

\subsection{Pro-Inflammatory and Anti-Inflammatory Cytokines}

The majority of the studies acknowledge that the periapical inflammation with the following bone destruction are mainly induced by the cytokines secreted in response to the bacterial infection within the root canal. Bacteria stimulate the secretion of proinflamatory cytokines, inlcuding: IL-1 $\beta$, IL-6, TNF- $\alpha$ [26-28].

There are pro-inflammatory and anti-inflammatory cytokines prsent within the periapical periodontitis. Both groups of cytokines play a significant role in the pathophisiology of the chronic inflammation in the area of periapical periodontium $[29,30]$. The pro-inflammatory cytokines (i.e., IL- $1 \alpha$, IL- 2 or TNF- $\alpha$ ) are mainly produced by the Th1 cells, macrophages and neutrophils. They take part in bacterially-induced bone resorption. In contrast, the anti-inflammatory cytokines (i.e., IL-4, IL-10) are produced by the Th2 cells and protect bone against destruction. Moreover, the anti-inflammatory cytokines participate in the healing process of the periapical lesions [28-31].

De Carvalho Fraga et al. [32] analyzed the levels of different cytokines in human radicular cysts and periapical granulomas. The authors found that IFN- $\gamma$ concentrations were increased in radicular cysts, whereas the expression of IL-4 was stronger in periapical granulomas. Furthermore, Walker KF et al. [33] showed, that Th2 cells and their products predominated in periapical lesions. In authors' opinion, the suppression of the inflammatory response combined with the increased number of Th2 lymphocyte subsets may directly affect the final outcome of the periapical pathological process.

Table 1 presents the general characteristics and functions of pro-inflammatory and anti-inflammatory cytokines which occur within the periapical lesions on the basis of the literature $[28,29,34-50]$. 
Table 1. General characteristics and functions of pro-inflammatory and anti-inflammatory cytokines which occur within the periapical lesions on the basis of the literature $[28,29,34-50]$.

\begin{tabular}{|c|c|c|c|c|c|}
\hline $\begin{array}{c}\text { Cytokine } \\
\text { (Abbreviation) }\end{array}$ & $\begin{array}{l}\text { Cytokine } \\
\text { Receptors }\end{array}$ & $\begin{array}{c}\text { Cytokine-Secreting } \\
\text { Cells }\end{array}$ & $\begin{array}{l}\text { Target } \\
\text { Cells }\end{array}$ & Functions & Bone Effect \\
\hline $\begin{array}{l}\text { Interleukin-1 } \\
\text { alpha } \\
(\mathrm{IL}-1 \alpha)\end{array}$ & $\begin{array}{l}\text { Interleukin-1 } \\
\text { receptor } \\
\text { (IL-1R): } \\
\text { type I (IL1R1) and } \\
\text { type II (ILL1R2) }\end{array}$ & $\begin{array}{l}\text { monocytes, macrophages, } \\
\text { polymorphonuclear } \\
\text { leucocytes (PMNs), } \\
\text { fibroblasts, osteoclasts, } \\
\text { epithelial cells, endothelial } \\
\text { cells, B cells }\end{array}$ & $\begin{array}{l}\text { T-cells, } \\
\text { B-cells, } \\
\text { neutrophils, } \\
\text { osteoblasts, } \\
\text { tissue cells }\end{array}$ & $\begin{array}{l}\text { Induces the inflammation } \\
\text { and regulates immune } \\
\text { system by chemotactically } \\
\text { activation of PMN. } \\
\text { Stimulates the production of } \\
\text { PG, proteolytic enzymes and } \\
\text { proinflammatory cytokines } \\
\text { IL-6, IL-8. }\end{array}$ & $\begin{array}{l}\text { Bone destruction: } \\
\text { stimulates bone resorption } \\
\text { and inhibits bone } \\
\text { formation. Inhibits } \\
\text { osteoblasts differentiation } \\
\text { and probably induces } \\
\text { apoptosis of osteoblasts. }\end{array}$ \\
\hline $\begin{array}{l}\text { Interleukin-1 beta } \\
\text { (IL-1 } \beta)\end{array}$ & $\begin{array}{l}\text { Interleukin-1 } \\
\text { receptor } \\
\text { (IL-1R): } \\
\text { type I (IL1R1) and } \\
\text { type II (ILL1R2) }\end{array}$ & $\begin{array}{l}\text { macrophages, dendritic } \\
\text { cells, osteoblasts, } \\
\text { fibroblasts (i.e., gingival } \\
\text { fibroblasts, periodontal } \\
\text { ligament cells), } \\
\text { osteoblasts, epithelial and } \\
\text { endothelial cells }\end{array}$ & $\begin{array}{c}\text { T-cells, } \\
\text { fibroblasts, } \\
\text { epithelial cells, } \\
\text { endothelial cells }\end{array}$ & $\begin{array}{c}\text { Induces the } \\
\text { inflammation: } \\
\text { accelerates blood flow in } \\
\text { inflamed tissue, supports } \\
\text { leucocyte recruitment and } \\
\text { neutrophil diffusion } \\
\text { and accumulation. }\end{array}$ & $\begin{array}{c}\text { Bone destruction: } \\
\text { promotes bone resorption } \\
\text { by stimulating production } \\
\text { of MMPs, (mainly } \\
\text { MMP-9), RANKL, IL-6. }\end{array}$ \\
\hline $\begin{array}{l}\text { Interleukin-18 } \\
\quad \text { (IL-18) }\end{array}$ & $\begin{array}{l}\text { Interleukin-18 receptor } \\
\quad \text { (IL-18R, CD218a) }\end{array}$ & $\begin{array}{l}\text { macrophages, dendritic } \\
\text { cells, monocytes, } \\
\text { keratinocytes, CNS cells, } \\
\text { osteoblasts, endothelial } \\
\text { cells }\end{array}$ & $\begin{array}{c}\text { T-cells } \\
\text { (CD4 and CD8), } \\
\text { NK-cells, } \\
\text { basophils, } \\
\text { mast cells }\end{array}$ & $\begin{array}{l}\text { Induces the production of } \\
\text { IFN } \gamma \text { by T-cells and } \\
\text { NK-cells. Induces Th } \\
\text { cell-mediated immunity. } \\
\text { Promotes proliferation } \\
\text { of Th1. }\end{array}$ & $\begin{array}{l}\text { Bone destruction: } \\
\text { promotes } \\
\text { osteoclastogenesis by } \\
\text { regulation of RANKL } \\
\text { production. }\end{array}$ \\
\hline $\begin{array}{l}\text { Interleukin-6 } \\
\quad \text { (IL-6) }\end{array}$ & $\begin{array}{l}\text { Interleukin-6 receptor } \\
\quad(I L-6 R, C D 126)\end{array}$ & $\begin{array}{c}\text { monocytes, } \\
\text { polymorphonuclear } \\
\text { leucocytes (PMNs), } \\
\text { osteoclasts, macrophages, } \\
\text { T-cells (Th2), B-cells, } \\
\text { fibroblasts, endothelial } \\
\text { cells }\end{array}$ & $\begin{array}{l}\text { T-cells, } \\
\text { B-cells, } \\
\text { neutrophils, } \\
\text { osteoblasts, } \\
\text { tissue cells }\end{array}$ & $\begin{array}{c}\text { Acute phase of } \\
\text { inflammation: activates } \\
\text { PMNs and T-cells. } \\
\text { Stimulates B-lymphocytes } \\
\text { differentiation into } \\
\text { plasma cell. } \\
\text { Induces protein synthesis. } \\
\text { Suppresses the production } \\
\text { of IL-1. }\end{array}$ & $\begin{array}{l}\text { Bone destruction: induces } \\
\text { bone resorption by } \\
\text { promoting osteoclast } \\
\text { differentiation. }\end{array}$ \\
\hline $\begin{array}{l}\text { Interleukin-8 } \\
\quad(\text { IL-8) }\end{array}$ & $\begin{array}{l}\text { Interleukin-8 receptor A } \\
\text { (IL-8RA, CXCR1) } \\
\text { and } \\
\text { interleukin-8 receptor B } \\
\text { (IL-8RB, CXCR2) }\end{array}$ & $\begin{array}{l}\text { monocytes, macrophages, } \\
\text { PMNs, bone marrow } \\
\text { stromal cells, osteoblasts, } \\
\text { osteoclasts, synovial } \\
\text { fibroblasts, chondrocytes }\end{array}$ & $\begin{array}{l}\text { neutrophils, } \\
\text { basophils }\end{array}$ & $\begin{array}{l}\text { Chemotactic factor: } \\
\text { attracts and activates PMNs } \\
\text { and osteoclasts. }\end{array}$ & $\begin{array}{c}\text { Bone destruction } \\
\text { (potentially): stimulates } \\
\text { osteoclastogenesis by } \\
\text { osteoclasts differentiation } \\
\text { and production, by } \\
\text { stimulating RANKL } \\
\text { expression and directly by } \\
\text { stimulation of osteoclasts } \\
\text { pro-duction } \\
\text { and activation. }\end{array}$ \\
\hline $\begin{array}{l}\text { Interleukin-10 } \\
\quad(\mathrm{IL}-10)\end{array}$ & $\begin{array}{l}\text { Interleukin-10 receptor: } \\
\text { (IL-10R) type I (IL-10R1) } \\
\text { and } \\
\text { type II (IL-10R2) }\end{array}$ & $\begin{array}{l}\text { T-cells, monocytes, } \\
\text { dendritic cells, B-cells, } \\
\text { mast-cells, eosinophils }\end{array}$ & $\begin{array}{l}\text { Th1, } \\
\text { macrophages, } \\
\text { NK-cells }\end{array}$ & $\begin{array}{l}\text { Inhibits the production of } \\
\text { cytokines by Th1: IL-1, IL-6 } \\
\text { and IFN } \gamma \text {. Inhibits synthesis } \\
\text { of NO and proteases (such as } \\
\text { collagenases). Stimulates the } \\
\text { secretion of tissue inhibitors } \\
\text { of metalloproteinases } \\
\text { and osteoprotegerin. }\end{array}$ & $\begin{array}{l}\text { Inhibits bone resorption, } \\
\text { suppresses the } \\
\text { osteoclastogenesis } \\
\text { and activates } \\
\text { proliferation } \\
\text { of osteoblasts. }\end{array}$ \\
\hline Interleukin-17 & $\begin{array}{l}\text { Interleukin-17 receptor } \\
\text { (IL-17R) }\end{array}$ & Th17, Tregs & $\begin{array}{l}\text { T-cells, B-cells, } \\
\text { osteoblasts, tissue } \\
\text { cells }\end{array}$ & $\begin{array}{l}\text { Induces the inflammation. } \\
\text { Activates secretion of IL-1, } \\
\text { IL-6, TNF } \alpha, \text { GCP-2 and IL- } 8 \text {. } \\
\text { Induces migration } \\
\text { of neutrophils. }\end{array}$ & $\begin{array}{c}\text { Bone destruction: } \\
\text { stimulates bone } \\
\text { resorption, stimulates the } \\
\text { production of RANKL by } \\
\text { osteoblast and } \\
\text { mesenchymal stem cells, } \\
\text { disturbs balance of } \\
\text { RANKL/OPG, which } \\
\text { promotes } \\
\text { osteoclastogenesis. }\end{array}$ \\
\hline $\begin{array}{l}\text { Tumor Necrosis } \\
\text { Factor } \alpha \\
(\text { TNF } \alpha)\end{array}$ & $\begin{array}{l}\text { Tumor necrosis factor } \\
\text { receptor } 1 \text { (TNFR1, } \\
\text { CD120a); } \\
\text { Tumor necrosis factor } \\
\text { receptor } 2 \text { (TNFR2, } \\
\text { CD120b) }\end{array}$ & $\begin{array}{c}\text { macrophages, monocytes, } \\
\text { lymphocytes (Th1), mast } \\
\text { cells }\end{array}$ & $\begin{array}{c}\text { macrophages, } \\
\text { granulocytes, } \\
\text { endothelial cells }\end{array}$ & $\begin{array}{l}\text { Induces the inflammation by } \\
\text { activating lymphocytes } \\
\text { and monocytes. }\end{array}$ & $\begin{array}{l}\text { Bone destruction: } \\
\text { stimulates bone } \\
\text { resorption, supports } \\
\text { osteoclastogenesis with } \\
\text { RANKL, promotes } \\
\text { differentiation of } \\
\text { osteoclasts and suppresses } \\
\text { formation of osteoblasts. }\end{array}$ \\
\hline
\end{tabular}


Table 1. Cont

\begin{tabular}{|c|c|c|c|c|c|}
\hline $\begin{array}{c}\text { Cytokine } \\
\text { (Abbreviation) }\end{array}$ & $\begin{array}{l}\text { Cytokine } \\
\text { Receptors }\end{array}$ & $\begin{array}{c}\text { Cytokine-Secreting } \\
\text { Cells }\end{array}$ & $\begin{array}{l}\text { Target } \\
\text { Cells }\end{array}$ & Functions & Bone Effect \\
\hline $\begin{array}{l}\text { Interferon gamma } \\
\quad(\text { IFN } \gamma)\end{array}$ & $\begin{array}{l}\text { Interferon gamma } \\
\text { receptor } 1 \text { (IFNGR1, } \\
\text { CD119) } \\
\text { and Interferon gamma } \\
\text { receptor } 2 \text { (IFNGR2) }\end{array}$ & $\begin{array}{l}\text { T-cells (CD4+, CD8+), Treg } \\
\text { cells, B-cells, NK cells }\end{array}$ & $\begin{array}{l}\text { monocytes, } \\
\text { lymphocytes, tissue } \\
\text { cells, mesenchymal } \\
\text { stem cells (MSCs) }\end{array}$ & $\begin{array}{l}\text { Activation of macrophages } \\
\text { and differentiation of B-cells. } \\
\text { Induces production of IL-1, } \\
\text { NO and oxygen. }\end{array}$ & $\begin{array}{l}\text { Inhibits bone resorption: } \\
\text { inhibits production and } \\
\text { differentiation of } \\
\text { osteoclasts, activates } \\
\text { apoptosis of osteoclasts. } \\
\text { Indirectly down-regulates } \\
\text { RANKL-depended } \\
\text { osteoclastogenesis. } \\
\text { Promotes differentiation } \\
\text { of osteoblast from MSCs. }\end{array}$ \\
\hline $\begin{array}{l}\text { Interleukin-4 } \\
\quad \text { (IL-4) }\end{array}$ & $\begin{array}{l}\text { Interleukin-4 receptor } \\
\quad(\mathrm{IL}-4, \mathrm{CD} 124)\end{array}$ & Th2 & Th17 & $\begin{array}{l}\text { Suppresses Th17 formation } \\
\text { and production of IL-1. } \\
\text { Stimulates the secretion of } \\
\text { tissue inhibitors of } \\
\text { metalloproteinases and } \\
\text { osteoprotegerin. }\end{array}$ & $\begin{array}{l}\text { Inhibits bone resorption, } \\
\text { inhibits the osteoclast } \\
\text { differentiation. It may } \\
\text { promote osteoprotegerin } \\
\text { pro-duction. }\end{array}$ \\
\hline $\begin{array}{c}\text { Granulocyte- } \\
\text { Macrophage } \\
\text { Colony Stimulating } \\
\text { Factor } \\
\text { (GM-CSF aka } \\
\text { CSF2) }\end{array}$ & $\begin{array}{l}\text { GM-CSF receptor } \\
\text { (GM-CSFR) }\end{array}$ & $\begin{array}{l}\text { macrophages, mast cells, } \\
\text { T-cells, fibroblasts, NK } \\
\text { cells, endothelial cells }\end{array}$ & $\begin{array}{l}\text { bone marrow stem } \\
\text { cells, macrophages, } \\
\text { neutrophils }\end{array}$ & $\begin{array}{l}\text { Takes part in hematopoiesis. } \\
\text { Induces production of } \\
\text { granulocytes (neutrophils, } \\
\text { basophils, eosinophils) and } \\
\text { monocytes from bone } \\
\text { marrow stem cells. Activates } \\
\text { macrophages. Enhances } \\
\text { neutrophils migration. }\end{array}$ & $\begin{array}{l}\text { Inhibits formation of } \\
\text { osteoclasts from } \\
\text { progenitor cells, reduces } \\
\text { the RANKL/RANK } \\
\text { activity. } \\
\text { The increased level of } \\
\text { dendritic cells makes } \\
\text { GM-CSF activate } \\
\text { osteoclastogenesis. }\end{array}$ \\
\hline
\end{tabular}

B-cell-lymphocyte type B, CD-cluster of differentiation, CNS cells-central nervous system cells, GCP-2-granulocyte chemotactic protein-2, IFN $\gamma$-interferon $\gamma$, IL-interleukin, MMP-matrix metalloproteinase, MSC-mesenchymal stem cell, NK-natural killer T-cell, NO-nitrous oxide, OPG-osteoprotegerin, PG-prostaglandin, PMN-polymorphonuclear leucocytes, RANK-Receptor Activator for Nuclear Factor $\mathrm{k}$ B, RANKL-Receptor Activator for Nuclear Factor k B Ligand, T-cell-lymphocyte type T, Th-T helper lymphocyte, TNF $\alpha$-tumor necrosis factor $\alpha$, Treg cell-regulatory T cell.

\subsection{The Role of MicroRNA (miRNA) in Bone Resorption and Pathogenesis of Apical Periodontitis}

MicroRNA (miRNA) is an endogenous, single-stranded, short (21 to 25 nucleotides), non-coding RNA that modulates post-transcriptional gene expression [51]. miRNA can bind to multiple mRNAs and lead to inhibition of protein translation or interfere with mRNA splicing. One mRNA can have multiple miRNA binding sites [52]. miRNA binds to the mRNA target sites, which are located in the $3^{\prime}$ untranslated regions $\left(3^{\prime} \mathrm{UTR}\right)$. This binding may stop the expression of transcripts, and consequently reduce the proteins quantity $[53,54]$.

Genes of miRNA are transcribed by RNA polymerase II into primary miRNAs (primiRNAs) [55]. pri-miRNAs are processed by Drosha/DGCR8 nuclear RNase III to a pre-miRNA. Then, this product is exported by Exportin-5 to the cytoplasm in a Ran-GTPdependent manner. In the cytoplasm the pre-miRNAs are transformed by RNase III Dicer to acquire the mature miRNAs [56,57].

Here, miRNA may quickly reduce the amount of proteins present within the cell by lowering their expression from the transcripts. miRNAs regulate the majority of cellular processes, including cell division, differentiation, aging, the course of their metabolism and finally apoptosis $[58,59]$. Furthermore, there may be a link between the miRNA activity and regulation of inflammation and oxidative stress [60].

In this case, miRNA was also found to play a significant role in the pathogenesis of apical periodontitis. Chan et al. [61] compared the expression of miRNAs in periapical lesions and healthy control tissues (normal periodontal ligament and pulp tissues). The material from periapical lesions was curetted from the bony cavity during the procedure of apicoectomy, performed in teeth with non-healing periapical lesions after root canal treatment. The authors identified 381 different miRNAs in periapical tissues, among which 24 miRNAs were down-regulated. One of the very important miRNAs' families, which appeared to be down-regulated, was the family of miR-181. The increase in the target messenger RNAs is the consequence of miRNAs downregulation. There have been listed several different miRNA targets, which affect both the inflammatory and immune response, including toll-like receptor-4 (TLR-4), interleukin-6 and -10 (IL-6, IL-10), chemokine ligand 
8 (CCL8), transforming growth factor beta 1 (TGF- $\beta 1$ ), vascular endothelial growth factor $\alpha$ (VEGF- $\alpha$ ) and metalloproteinase-9 (MMP-9) [61]. The miR-181a, miR-181b and miR-181c, miR-24-1, miR-95, miR-149 and miR-455-3p were detected in altered periapical tissues [61]. miRNA is also believed to regulate osteoclastogenesis [62]. The mineralized bone matrix is degraded by osteoclasts. Metalloproteinases (MMPs), which are one of the targets of the miRNA, were found to be able to degrade bone organic matrix [61,63]. Lack of miRNA activity inhibits osteoclast precursor cells to produce osteoclasts. Without the presence of miRNAs, the number of osteoclasts becomes reduced. Therefore, the amount of resorbed bone is limited [62]. miRNA-21 is a well-known miRNA, that promotes osteoclastogenesis and osteogenic differentiation of mesenchymal stem cells $[64,65]$. It also regulates skin wound healing and affects collagen deposition [66]. Moreover, mi-RNA-21 is also a marker of chronic inflammation in diabetes mellitus (DM) [67]. miRNAs have been found to regulate the inflammation and oxidative stress, two processes which affect bone healing in the course of DM [65]. Baćević et al. [65] found that the usage of leukocyte- and platelet-rich fibrin (L-PRF) improved cranial bone healing in diabetics rabbits, by increasing expression levels of miRNA-21 and by reducing oxidative stress. It seems that L-PRF used either alone or with Bio-Oss as bone graft may be efficient in DM, because of affecting the expression of miRNA-21 [65].

Table 2 presents the exemplary miRNA occurring within the periapical lesions on the basis of the literature $[61,68-72]$.

Table 2. Exemplary miRNA occurring within the periapical lesions on the basis of the literature [61,68-72].

\begin{tabular}{ccr}
\hline MicroRNA (miRNA) & Gene & Effect \\
\hline miRNA-155 & $21 \mathrm{q} 21.3$ & $\begin{array}{c}\text { Inhibition of SEMA3A. } \\
\text { Decreased expression of SEMA3A contributes to bone resorption. }\end{array}$ \\
\hline miRNA-335-5p & $7 \mathrm{q} 32.2$ & In inflamed HPDLFs promotes bone resorption (RANKL). \\
\hline miRNA-181b-5p & $1 \mathrm{q} 32.1$ & $\begin{array}{c}\text { Positive regulation of: acute inflammation (activation of NK-cells, monocytes, T-cells), } \\
\text { angiogenesis, macrophages differentiation. Cementoblasts apoptosis. }\end{array}$ \\
\hline miRNA-146a & $5 \mathrm{q} 33.3$ & $\begin{array}{c}\text { Anti-inflammatory activity. } \\
\text { Negative regulation of IL-6, IL-1 } \beta \text { and TNF- } \alpha .\end{array}$ \\
\hline miRNA-10a-5p & $17 \mathrm{q} 21.32$ & Reduction of inflammation. Healing of apical periodontitis.
\end{tabular}

SEMA3A-Semaphorin 3A, HPDLFs-Human Periodontal Ligament Fibroblasts, RANKL-Receptor Activator for Nuclear Factor $\mathrm{k}$ B Ligand, T-cell-lymphocyte type T, NK-natural killer T-cell, IL-6-Interleukin 6, IL-1 $\beta$-Interleukin 1 beta, TNF $\alpha$-Tumor Necro-sis Factor.

\section{Endodontic Treatment of Periapical Lesions}

Endodontic periapical lesions are typically one of the indications for an endodontic treatment. In case of larger lesions, with a diameter greater than or equal to $8 \mathrm{~mm}$, it is recommended to perform two-visit therapy [8]. In two-stands treatment, the root canal is temporarily filled between visits, usually with a medication based on a non-hardening calcium hydroxide $\left(\mathrm{Ca}(\mathrm{OH})_{2}\right)$.

Non-hardening $\mathrm{Ca}(\mathrm{OH})_{2}$ has a bactericidal effect, stimulates tissue mineralization and finally induces the processes of regeneration and repair of periapical lesions [73-75]. A temporary $\mathrm{Ca}(\mathrm{OH})_{2}$ filling is typically left in the root canal for 3 weeks, and should not be left for longer than 3 months. This period of time seems to be sufficient to observe healing of periapical lesions, both clinically and radiologically. Finally, after this period of time, the temporary filling material is removed from the root canal, and the endodontic treatment can be completed [8]. According to the recent researches, a long-lasting effect of $\mathrm{Ca}(\mathrm{OH})_{2}$ for many months is denied. To eliminate sufficiently microbiota from root canal, it is enough to temporarily fill the root canal with non-hardening $\mathrm{Ca}(\mathrm{OH})_{2}$ for one week [76]. Peters and Wesselink [77] compared the efficacy of two visit endodontic treatment (with the use of $\mathrm{Ca}(\mathrm{OH})_{2}$ as a temporal filler of the root canal) with the single visit root canal treatment (canals were obturated with gutta-percha and AH-26 sealer without the use of 
any temporal fillers). The authors did not notice any significant differences regarding the process of periapical lesions' healing.

However, it should be emphasized that mechanical removal of infected dentin and proper irrigation with antibacterial agents (most commonly used: sodium hypochlorite $(\mathrm{NaOCl})$, chlorhexidine (CHX), ethylenediaminetetraacetic acid (EDTA) and mixture of tetracycline, acid and detergent (MTDA)) lead to almost complete elimination of bacteria from the root canal system [78]. Rodrigues et al. [79] conducted the clinical trial among patients who underwent endodontic treatment of the teeth due to chronic periodontitis and found that chemomechanical root canal preparation is highly efficient method of root canal eradication (eradication at the level of 83.7 to $96.7 \%$ ). The efficiency of the irrigation process may be even increased with the ultrasonic activation of irrigants [80]. The recommended protocol for the final root canal irrigation is the combination of $5.25 \%$ sodium hypochlorite (in two cycles with ultrasonic activation), $40 \%$ citric acid and distilled water to reduce sodium hypochlorite and to neutralize citric acid [81].

Orstavik [82] found that almost $85 \%$ of periapical lesions healed within 48 months. However, only $42.5 \%$ of the lesions were in the process of healing 6 months after the end of endodontic treatment. According to the European Society of Endodontology guidelines, it is recommended to observe the periapical lesion for at least 4 years before further, more radical procedures will be performed. Healing of the periapical lesions is considered to be a prolonged process [26].

When RCT is not successful, the surgical procedures are performed. The aim of the endodontic surgical procedure is to remove the root apex with the adjacent inflammatory periapical lesion. There are different surgical procedures used for the treatment of periapical lesions, including the resection of the root apex, and hemisection, which aims to remove one root (in case of multi-rooted teeth), leaving the remaining ones undamaged [83,84]. Unfortunately, there are several complications related to the endodontic surgical procedures, including excessive bone loss, bleeding, damage to the adjacent anatomical structures (e.g., nerve bundles), periodontal complications such as a gingival recession or formation of an astringent scar [85]. As an alternative to a conventional surgery, microsurgical procedures can be carried out with the use of operating microscopy. The biggest advantage of microsurgical endodontics is minimizing the amount of a removed bone tissue. Due to the careful revision of the operation area, it is possible to perform the procedure precisely, and reduce the incidence of complications [85-87]. In addition, the retro preparation field and selection of the ultrasonic tip allow a more conservative approach to preserve more bone tissues [88].

When none of the abovementioned groups of methods of treatment is successful, the tooth is qualified for extraction $[89,90]$. The missing tooth always needs to be restored to maintain the stability of the entire stomatognathic system. If the missing tooth is not restored, the neighboring and opposite teeth start moving towards the space after the extracted tooth. Therefore, the disturbances in occlusion become created [89-91].

\section{Platelet Concentrates-General Characteristics, and Role in the Endodontic Treatment}

Platelets (PLT, thrombocytes) are the smallest blood components with a diameter of about $2.5 \mu \mathrm{m}$. They are fragments of megakaryocyte cytoplasm, surrounded by a cell membrane, devoid of a cell nucleus. The remaining cell organelles are typical for eukaryotic cells. Thrombocytes are characterized by an active metabolism, a highly organized cytoskeleton, as well as a presence of specific intracellular granules and adhesive proteins located on the surface of the PLT. Thrombocytes are terminally differentiated cells [21,92].

Platelets play a significant role in hemostasis. After a blood vessel interruption, platelets participate in the processes of activation, adhesion and aggregation. They also release substances contained in their granules. Platelets are also effector cells of the innate immune system. They can bind pathogens directly or indirectly through the receptor proteins (including TLR2, TLR4, TLR7, TLR9, etc.), to present them to neutrophils and cells 
of the reticuloendothelial system $[21,92,93]$. The potential regenerative effect of platelets was first described by Ross et al. in 1974 [94].

In order to separate platelets from other blood elements, a centrifugation is carried out. Heavier elements fall down to the bottom of the tube, whereas the lighter ones float above. The lower layer consists of erythrocytes, while the upper one is composed of plasma. A platelet-leukocyte layer forms between these two fractions. The concentration of platelets in plasma is several times higher than in a non-centrifuged blood. This directly leads to an increased concentration of: PDGF, TGF $\beta$, integrins and other adhesion molecules [23].

There are two major types of PRF according to the current classification of platelet concentrates from 2009: P-PRF (pure platelet rich fibrin) and L-PRF (leukocyte and platelet rich fibrin) [95].

P-PRF, also known as leukocyte-poor platelet-rich fibrin, is an autologous material without leukocytes and with a high-density fibrin network. It only exists in a strongly activated gel form, therefore it cannot be injected. On the basis of the literature, there is currently only one commercially available P-PRF product-Fibrinet PRFM (Platelet-Rich Fibrin Matrix, Cascade Medical, Wayne, NJ, USA), which is mostly used in orthopedics and sports medicine. The huge disadvantage of using P-PRF is its cost comparing to L-PRF [95-97].

Leukocyte and platelet rich fibrin (L-PRF) consists of leukocytes and a high-density fibrin network. There are two subcategories of L-PRF: A-PRF (advanced platelet rich fibrin) and i-PRF (injectable platelet rich fibrin) $[96,97]$. Their newest generations are named: A-PRF+ and i-PRF+. The novelty in obtaining platelet-rich fibrin refers to reduced centrifugation speed and time $[98,99]$.

Newly invented PRF centrifugation protocols improve tissue regeneration [100]. The standard PRF is centrifuged at $2700 \mathrm{rpm}$ for $12 \mathrm{~min}$. Whereas to obtain the A-PRF, the blood is centrifuged at lower speeds, namely: $1500 \mathrm{rpm}$ for $14 \mathrm{~min}$. This modification of the centrifugation protocol leads to significant increase in the release of growth factors (PDGF, TGF- $\beta 1$, epidermal growth factor (EGF), insulin-like growth factor (IGF)) in the application area, with a higher number of progenitor cells [99-101].

The main role of fibrin in the process of healing is hemostasis. However, it also regulates migration of fibroblasts and endothelial cells, which are involved in angiogenesis and are responsible for the new tissue formation. An important feature of PRF is the prolonged release of growth factors for at least 7 days at the application site [98]. Growth factors and released cytokines stimulate the activity of osteoblasts. The release of growth factors accelerates tissue regeneration by increasing the migration of fibroblasts $[92,98,102,103]$. VEGF stimulates angiogenesis, which is a crucial part of bone regeneration, as the blood supply promotes osteogenesis. It has been shown that angiogenesis occurs before osteogenesis in the healing of bone defects. VEGF can induce the mobilization, recruitment, proliferation and differentiation of endothelial progenitor cells (EPCs) as well osteoblast recruitment and survival [104].

The leukocytes within L-PRF present antimicrobial properties. They can act directly (i.e., phagocytosis) [105] or indirectly, presenting immunomodulatory activity (i.e., antibodies production) [106]. Kour et al. [107] found that three different platelet concentrates, namely: PRP, PRF and i-PRF, show antibacterial ability against periopathogens present in the oral cavity, including Porphyromonas gingivalis (P.g.) and Aggregatibacter actinomycetemcomitans (A.a.). The authors measured the width of inhibition zones to assess the antimicrobial properties of particular platelet concentrates. In case of P.g., i-PRF and PRP had significantly wider zones of inhibition comparing to PRF. In case of A.a., PRP had bigger zone of inhibition than PRF and i-PRF. Regarding the antibacterial properties against A.a., there were no significant differences between PRF and i-PRF [107].

Platelet concentrates, including PRF and PRP, are widely used in regenerative medicine, as well as in dentistry $[108,109]$. PRF can be used alone or in combination with other biomaterials. There are several different uses of platelet concentrates in dentistry, including: endodontic treatment of permanent teeth with incomplete apex development (pulpotomy, 
revascularization and apexification), guided bone regeneration (alveolar bone augmentation, sinus lifting), periodontal treatment (plastic periodontology surgery, treatment of bone loss defects). Moreover, the use of PRF in guided tissue regeneration scaffold has been the subject of extended investigations [110-115].

\section{Mesenchymal Stem Cells and Platelet Concentrates}

Mesenchymal stem cells (MSCs) are pluripotent, which means they can differentiate into various types of cells, i.e., osteoblasts, chondrocytes or adipocytes [116]. MSCs suppress the immune response. MSCs reduce the lymphocytes' immunological responses, affect antigen-presenting cells by inhibiting their maturation, and finally reduce the immune activity of NK cells [116,117]. The above presented features of MSCs allow mesenchymal cells to take part in the regeneration processes $[116,118]$. There are several different types of stem cells involved into the regeneration processes of dental pulp cells, including stem cells of the apical papilla (SCAPs), periodontal ligament stem cells (PDLSCs) and human dental pulp cells (hDPCs) $[119,120]$. It has already been proven that autologous platelet concentrate may be a carrier for bone marrow mesenchymal stem cells (BMSCs) [121] and may stimulate the processes of proliferation and differentiation of BMSCs [122]. Sequeira et al. [123] used PRP as a scaffold for SCAPs and found that SCAPs induced formation of dentin-like and pulp-like tissues.

Xu et al. [124] analyzed the effects of concentrated growth factor (CGF) on human dental pulp stem cells (hDPSCs), which were exposed to lipopolysaccharide (LPS). The authors found that LPS stimulates the expression of proinflammatory cytokines in hDPSCs. Dental pulp cells chronically exposed to proinflammatory cytokines lose their ability to differentiate to osteoblasts. Xu et al. [124] noticed that CGF limited the release of proinflammatory cytokines and stimulated proliferation, migration and differentiation of hDSPCs. Rochira et al. [125] observed that CGF alone can stimulate osteogenic differentiation of human Bone Marrow Stem Cells (hBMSCs). According to the study by Zhang et al. [126], both the CGF and L-PRF release growth factors, including bFGF, TGF- $\beta 1$ and bone morphogenetic protein 2 (BMP-2), which affect the differentiation of mesenchymal stem cells and lead to bone formation. The authors noticed that BMP-2 is released slowly for at least 7 days in CGF and L-PRF. Finally, Li et al. [127] summarized that CGF stimulates proliferation of different types of mesenchymal stem cells, including DPSCs, PDLSCs, as well as human mesenchymal stem cells (hTERT-E6/E7) in a dose-dependent manner.

\section{PRF in the Endodontic Treatment of Permanent Teeth with Closed Apexes}

The clinical effects of conventional RCT with an additional supplementation of PRF in the treatment of permanent teeth with closed apexes, diagnosed with periapical lesions, have been examined only by Machut et al. [128]. The authors presented two case reports with satisfactory bone healing 6 months after the end of RCT. The authors applied A-PRF membrane by the apical foramen to the periapical area. Permanent, mature teeth with closed apexes have mostly been treated with different types of PRF used as bone fillers (either alone or mixed with bone substitutes), and/or membranes placed over the bone defects in terms of endodontic surgery.

Soto-Peñaloza et al. [129] presented randomized clinical trial, which assessed the clinical effects of the use of A-PRF+ membranes in the endodontic surgery. This is the only one randomized clinical trial which analyzes the outcomes of PRF use in endodontic treatment of permanent teeth with closed apexes. The authors did not observe significant differences between the groups regarding postoperative pain. Moreover, only sleep and speech functions presented more limitations in control group.

All of the published case reports [130-141] revealed satisfactory bone healing after placing PRF or PRF mixed with bone substitutes inside the bone defects. However, they do not explain and answer the fundamental question if additional use of PRF in endodontic surgery is more beneficial for the patient than the conventional surgical procedures performed without any additional supplementation. Only Parikh et al. [141] compared the 
results of RCT and curettage of the defect with the results of RCT and curettage of the defect and additional PRF gel supplementation, performed in two upper central incisors in one patient. The authors noticed that additional use of PRF led to better bone healing.

Table 3 presents the use of PRF in the endodontic treatment of permanent teeth with closed apexes on the basis of the literature [128-141].

Table 3. PRF in the endodontic treatment of permanent teeth with closed apexes on the basis of the literature [128-141].

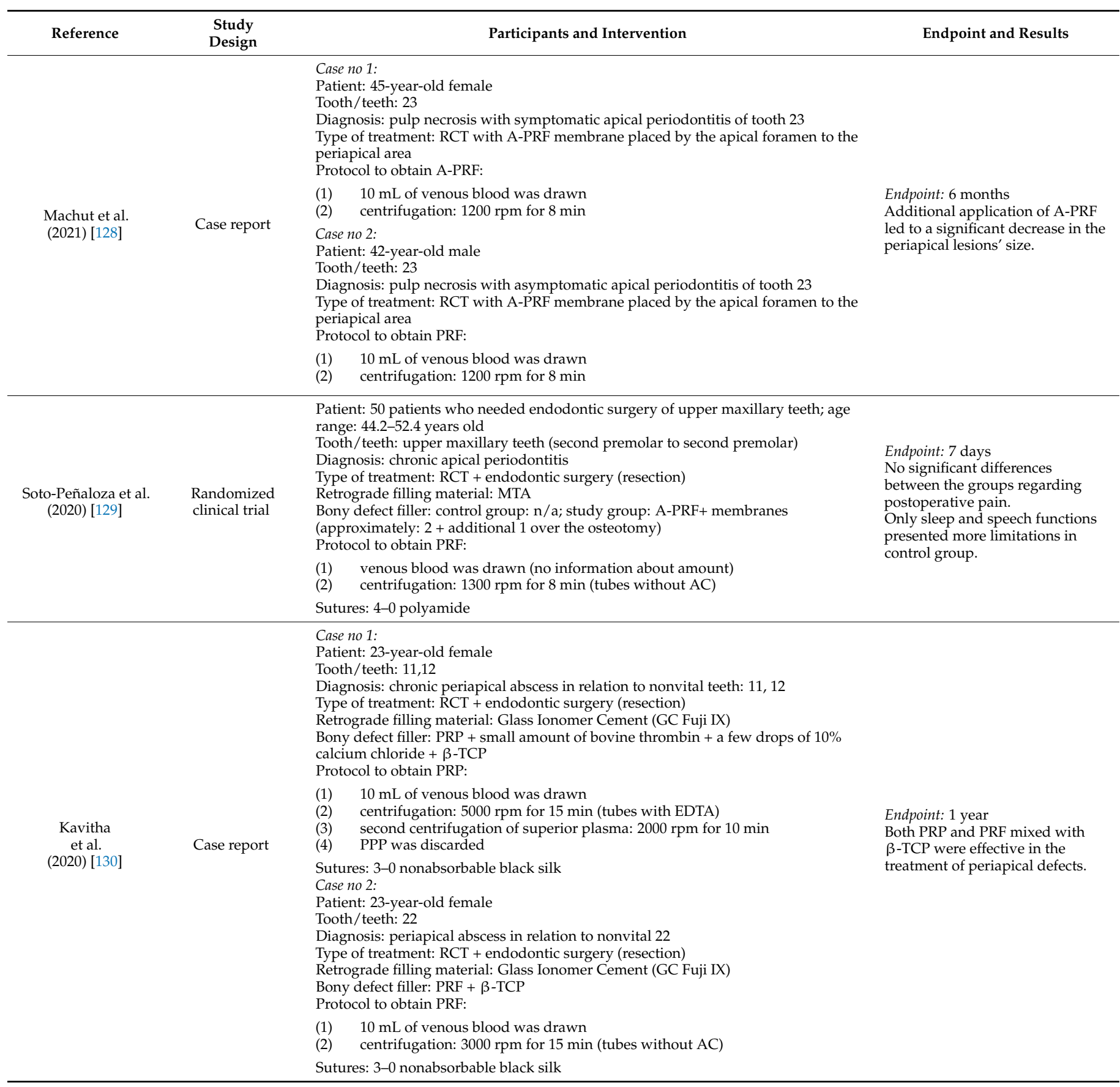


Table 3. Cont

\begin{tabular}{|c|c|c|c|}
\hline Reference & $\begin{array}{l}\text { Study } \\
\text { Design }\end{array}$ & Participants and Intervention & Endpoint and Results \\
\hline \multirow[t]{2}{*}{$\begin{array}{l}\text { Sureshbabu } \\
\text { et al. } \\
\text { (2020) [131] }\end{array}$} & \multirow[t]{2}{*}{ Case report } & $\begin{array}{l}\text { Patient: } 26 \text {-year-old male } \\
\text { Tooth/teeth: } 43,44,45 \\
\text { Diagnosis: pulpal necrosis with a chronic apical abscess in } 43,44,45 \\
\text { Type of treatment: RCT + endodontic surgery (resection) } \\
\text { Retrograde filling material: MTA } \\
\text { Bony defect filler: CGF + osseograft + CGF membrane } \\
\text { Protocol to obtain CGF: } \\
\text { (1) } 20 \mathrm{~mL} \text { of venous blood was drawn } \\
\text { (2) acceleration for } 30 \mathrm{~s} \text {; centrifugation at } 2700 \mathrm{rpm} \text { for } 2 \mathrm{~min}, 2400 \mathrm{rpm} \text { for } \\
4 \text { min, } 2700 \mathrm{rpm} \text { for } 4 \text { min, } 3000 \mathrm{rpm} \text { for } 3 \mathrm{~min} \text {; deceleration for } 36 \mathrm{~s} \\
\text { (3) centrifugation of superior plasma: } 2000 \mathrm{rpm} \text { for } 10 \text { min }\end{array}$ & \multirow[t]{2}{*}{$\begin{array}{l}\text { Endpoint: } 1 \text { year and } 2 \text { years } \\
\text { After } 1 \text { year, lesion reduction size } \\
\text { was found to be } 79 \% \text {. }\end{array}$} \\
\hline & & Sutures: $3-0$ vicryl & \\
\hline $\begin{array}{c}\text { Taschieri } \\
\text { et al. } \\
\text { (2012) [132] }\end{array}$ & Case report & $\begin{array}{l}\text { Patient: } 28 \text {-year-old male } \\
\text { Tooth/teeth: } 21,22 \\
\text { Diagnosis: periradicular lesion of endodontic origin, vestibular sinus tract and an } \\
\text { abscess on the palatal side, nonvital tooth } 22 \text {, tooth } 21 \text { after RCT with large } \\
\text { endodontic post } \\
\text { Type of treatment: RCT + endodontic surgery (resection) } \\
\text { Retrograde filling material: } \mathrm{n} / \mathrm{a} \\
\text { Bony defect filler: PRGF }+50 \mu \mathrm{L} \text { of } 10 \% \mathrm{CaCl} 2 \text { were added per cubic centimeter of } \\
\text { PRGF concentrate + Bio-Oss mixed with PRGF + BioGide membrane } \\
\text { Protocol to obtain PRGF: } \\
\text { (1) } 5 \text { mL of venous blood was drawn } \\
\text { (2) centrifugation: } 460 \times g \text { for } 8 \text { min (tubes with } 3.8 \% \text { trisodium citrate) } \\
\text { Sutures: non-absorbable silk } 5-0\end{array}$ & $\begin{array}{l}\text { Endpoint: } 1 \text { year } \\
\text { After } 1 \text { year the authors noticed } \\
\text { complete healing and } \\
\text { functionality. }\end{array}$ \\
\hline \multirow[t]{2}{*}{$\begin{array}{l}\text { Shivashankar et al. } \\
\text { (2013) [133] }\end{array}$} & \multirow[t]{2}{*}{ Case report } & $\begin{array}{l}\text { Patient: } 45 \text {-year-old male } \\
\text { Tooth/teeth: } 12,11 \\
\text { Diagnosis: exacerbated chronic periodontitis in relation to nonvital teeth: } 11,12 \\
\text { Type of treatment: RCT + endodontic surgery (resection) } \\
\text { Retrograde filling material: MTA } \\
\text { Bony defect filler: PRF + HA bone graft crystals + PRF membrane } \\
\text { Protocol to obtain PRF: } \\
\text { (1) } 20 \mathrm{~mL} \text { of venous blood was drawn } \\
\text { (2) centrifugation: } 3000 \mathrm{rpm} \text { for } 10 \mathrm{~min}\end{array}$ & \multirow[t]{2}{*}{$\begin{array}{l}\text { Endpoint: } 2 \text { years } \\
\text { The authors noticed complete } \\
\text { bone healing after } 2 \text { years. }\end{array}$} \\
\hline & & Sutures: 3-0 black silk suture material & \\
\hline $\begin{array}{l}\text { Zhao et al. } \\
\text { (2014) [134] }\end{array}$ & Case report & $\begin{array}{l}\text { Case no 1: } \\
\text { Patient: } 28 \text {-year-old female } \\
\text { Tooth/teeth: } 13,12,21,22 \\
\text { Diagnosis: exacerbated chronic periodontitis in relation to nonvital teeth: } 13,12 \text {, } \\
\text { 21,22; incomplete root canal fillings of teeth no: } 12,21,22 \\
\text { Type of treatment: RCT + endodontic surgery (resection) } \\
\text { Retrograde filling material: amalgam } \\
\text { Bony defect filler: minced PRF mixed with resorbable bioactive glass + PRF } \\
\text { membrane } \\
\text { Protocol to obtain PRF: } \\
\text { (1) venous blood was drawn (no information about amount) } \\
\text { (2) centrifugation: } 3000 \text { rpm for } 12 \text { min (tubes without anticoagulant) } \\
\text { Sutures: } 4-0 \text { silk } \\
\text { Case no 2: } \\
\text { Patient: } 27-y e a r-o l d ~ f e m a l e \\
\text { Tooth/teeth: } 14,13,12,21,22 \\
\text { Diagnosis: exacerbated chronic periodontitis in relation to nonvital teeth: } 14,13 \text {, } \\
\text { 12,11,21; incomplete root canal fillings of teeth no: } 14,13,12,11,21 \\
\text { Type of treatment: RCT + endodontic surgery (resection) } \\
\text { Retrograde filling material: amalgam } \\
\text { Bony defect filler: minced PRF mixed with resorbable BG + PRF membrane } \\
\text { Protocol to obtain PRF: } \\
\text { (1) venous blood was drawn (no information about amount) } \\
\text { (2) centrifugation: } 3000 \text { rpm for } 12 \text { min (tubes without anticoagulant) } \\
\text { Sutures: } 4-0 \text { silk }\end{array}$ & $\begin{array}{l}\text { Endpoint: } \\
7 \text { months (1st case) } \\
4 \text { months ( } 2 \text { nd case) } \\
\text { The authors noticed satisfactory } \\
\text { bone healing at the endpoint } \\
\text { examination. }\end{array}$ \\
\hline $\begin{array}{l}\text { Dudeja et al. } \\
\text { (2017) [135] }\end{array}$ & Case report & $\begin{array}{l}\text { Patient: } 26 \text {-year-old female } \\
\text { Tooth/teeth: } 21,22 \\
\text { Diagnosis: chronic periodontitis in relation to nonvital teeth: } 21,22 \text {; suppurative } \\
\text { sinus tract between teeth } 22 \text { and } 23 \\
\text { Type of treatment: RCT + endodontic surgery (resection) } \\
\text { Retrograde filling material: MTA } \\
\text { Bony defect filler: PRF membrane + PRF mixed with an irradiated FDBA + } \\
\text { collagen membrane } \\
\text { Protocol to obtain PRF: } \\
\text { (1) venous blood was drawn (no information about amount) } \\
(2) \quad \text { centrifugation: } n / a \\
\text { Sutures. } 3-0 \text { silk }\end{array}$ & $\begin{array}{l}\text { Endpoint: } 1 \text { year } \\
\text { After } 1 \text { year the authors observed } \\
\text { continuation of healing process } \\
\text { and decrease in the size of } \\
\text { radiolucency. }\end{array}$ \\
\hline
\end{tabular}


Table 3. Cont

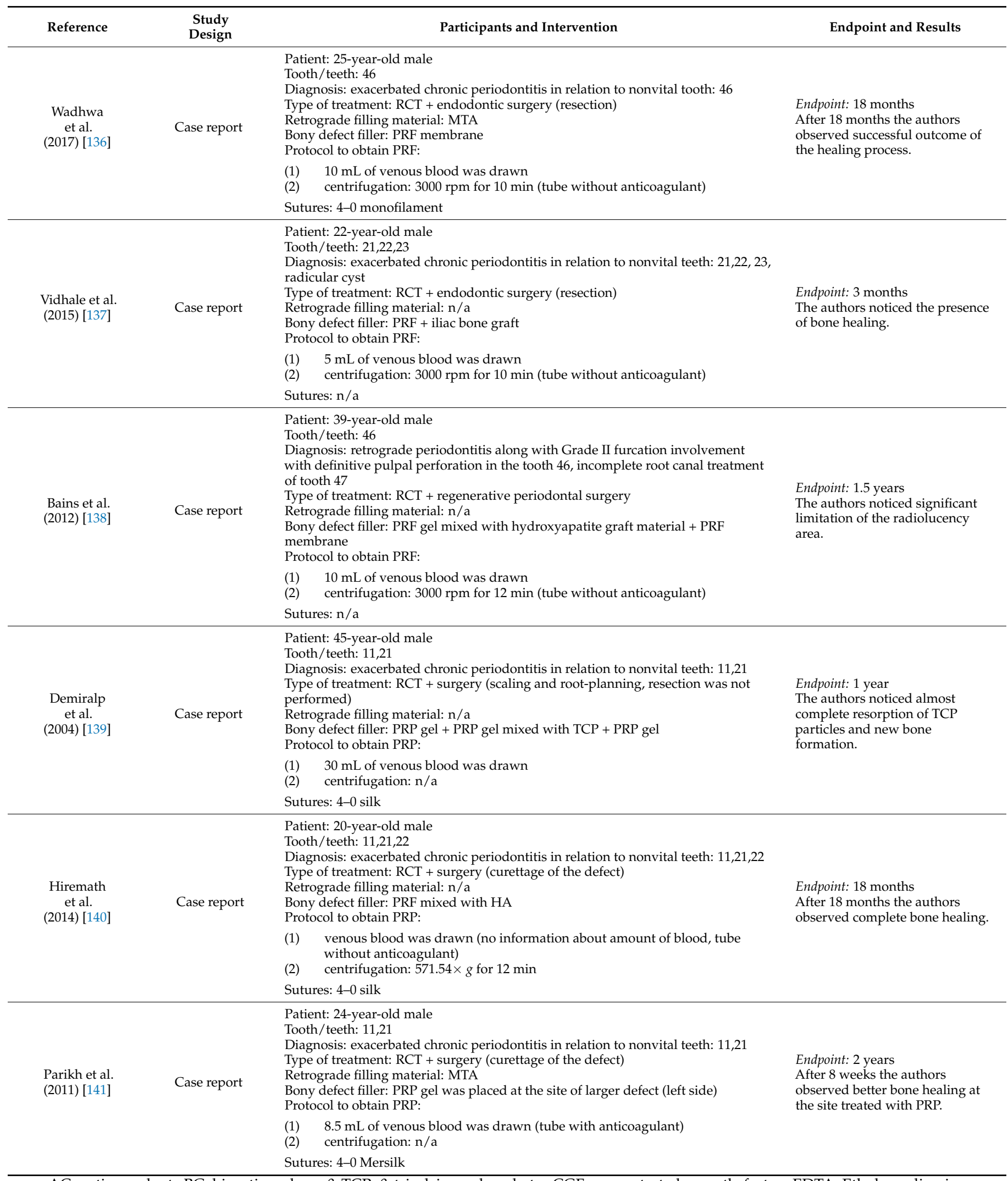

AC-anticoagulant, BG-bioactive glass, $\beta$-TCP- $\beta$-tricalcium phosphate, CGF-concentrated growth factor, EDTA-Ethylene diamine tetraacetic acid, FDBA-freeze-dried bone allograft, HA-hydroxyapatite, MTA-Mineral Trioxide Aggregate, n/a-not applicable, PPP-platet poor plasma, RCT-root canal treatment, TCP-tricalcium phosphate. 


\section{Materials and Methods}

\subsection{Clinical Question}

What is the clinical efficacy of plasma rich in growth factors (PRGF) applied in the periapical region supplementary to conventional root canal treatment (RCT) of permanent teeth with closed apexes, diagnosed with periapical lesions, on the basis of the literature?

\subsection{Inclusion and Exclusion Criteria for the Narrative Review}

Table 4 presents inclusion and exclusion criteria for the narrative review.

Table 4. Inclusion and exclusion criteria for the narrative review.

\begin{tabular}{|c|c|}
\hline Criteria & List of Specific Criteria \\
\hline \multirow{6}{*}{$\begin{array}{l}\text { Inclusion } \\
\text { criteria }\end{array}$} & randomized controlled trials \\
\hline & randomized clinical trials \\
\hline & case reports \\
\hline & case-control studies \\
\hline & $\begin{array}{c}\text { study population: adult patients (aged: } 18 \text { years old or more); permanent teeth with } \\
\text { closed apexes, diagnosed with periapical lesions }\end{array}$ \\
\hline & methods of treatment: RCT with application of PRGF \\
\hline \multirow{6}{*}{$\begin{array}{l}\text { Exclusion } \\
\text { criteria }\end{array}$} & systematic reviews and metanalyses \\
\hline & comments \\
\hline & animal studies \\
\hline & $\begin{array}{l}\text { study population: children with deciduous teeth, children and adolescents with } \\
\text { immature teeth (teeth with opened apexes), teeth without periapical lesions }\end{array}$ \\
\hline & $\begin{array}{c}\text { methods of treatment: endodontic procedures without application of PRGF, } \\
\text { endodontic surgery }\end{array}$ \\
\hline & papers written in languages other than English \\
\hline
\end{tabular}

PRGF-plasma rich in growth factors; RCT-root canal treatment.

\subsection{The PICO Approach}

We used the PICO approach to properly develop literature search strategies for this review:

Population: adolescents and adult patients; only mature teeth with closed apexes diagnosed with periapical lesion.

Intervention: RCT with additional application of PRGF or RCT with endodontic surgery with additional direct application of PRGF.

Comparison: RCT without additional application of PRGF; RCT with endodontic surgery without additional application of PRGF; placebo.

Outcome: healing of the periapical lesion and tooth pain reduction (in case of symptomatic periapical periodontitis).

\subsection{Search Strategy}

The PubMed database was analyzed with the following keywords: ((PRP) OR (PRF) OR (PRGF) OR (CGF)) AND (endodontic) AND ((treatment) OR (therapy)). After screening of 155 results, 14 studies were included in this review (one randomized controlled trial and 13 case reports).

Figure 1 presents the PRISMA flow diagram for a review of the literature. 


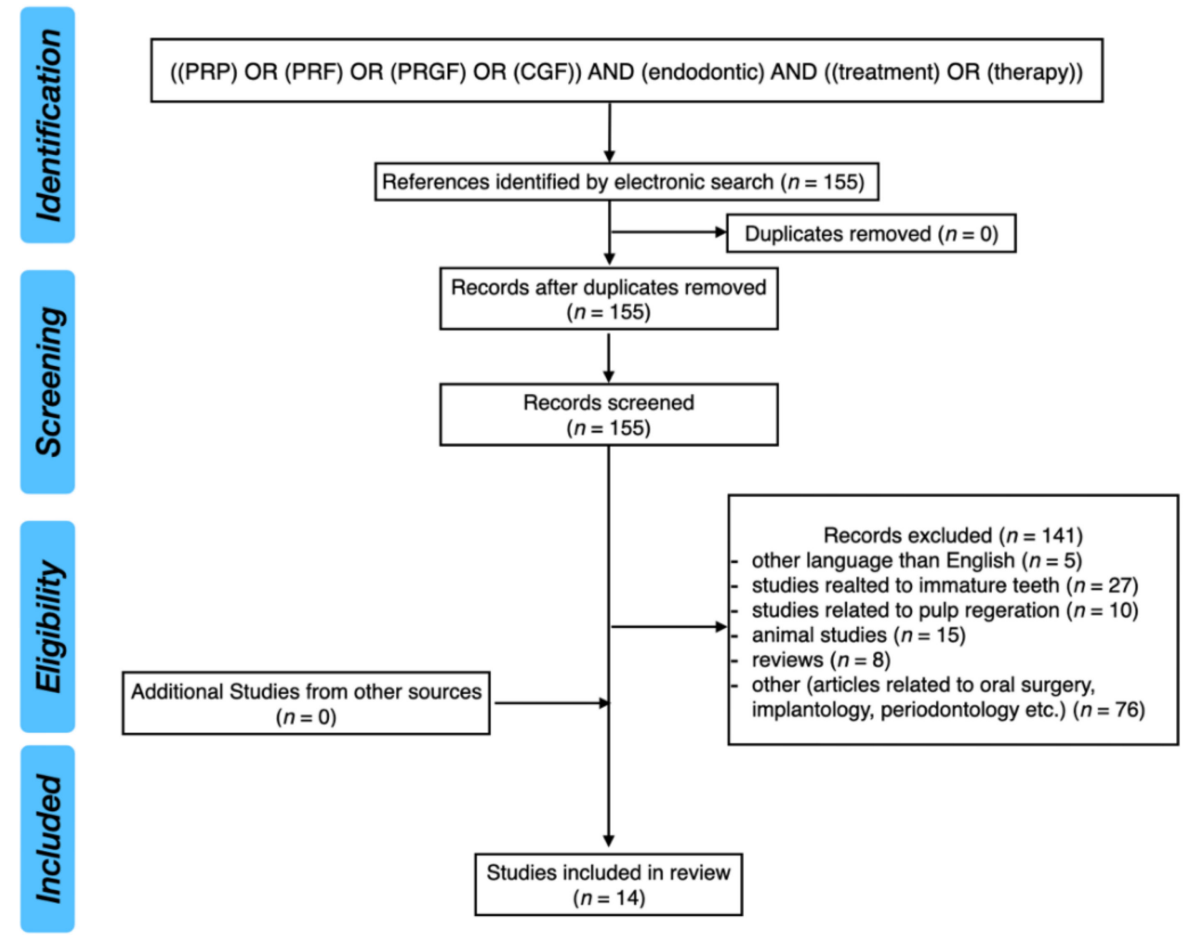

Figure 1. PRISMA flow diagram for review of the literature.

\section{Conclusions}

Different types of platelet concentrates, especially L-PRF and CGF, are able to stimulate the processes of proliferation and differentiation of mesenchymal stem cells. They induce the bone regeneration processes. Moreover, it has also been proven that L-PRF may affect the expression of miRNA-21.

Despite the fact, that PRF seems to promote bone healing and to reduce healing time, it was not possible to assess the efficacy of PRF supplementation in the treatment of endodontic periapical lesions in permanent, mature teeth with closed apexes, due to the lack of well-designed scientific research. Further studies, especially randomized doubleblind controlled trials, are needed to assess whether the RCT with additional application of PRF is superior to RCT performed alone in the treatment of permanent mature teeth with closed apexes diagnosed with periapical lesions.

Author Contributions: Conceptualization, K.M., M.D. and A.Z.; methodology, K.M., A.Z. and M.D.; validation, K.M., A.Z. and M.D.; formal analysis, K.M. and M.D.; investigation, K.M., M.D. and A.Z.; resources, K.M. and M.D.; writing—original draft preparation, K.M. and M.D.; writing-review and editing, A.Z., M.D. and E.P.; supervision, M.D., A.Z. and E.P.; project administration, K.M., A.Z. and M.D. All authors have read and agreed to the published version of the manuscript.

Funding: This research received no external funding.

Institutional Review Board Statement: Not applicable.

Informed Consent Statement: Not applicable.

Data Availability Statement: All data are contained within the article.

Conflicts of Interest: The authors declare no conflict of interest.

\section{References}

1. Cho, M.I.; Garant, P.R. Development and general structure of the periodontium. Periodontology 2000 2000, 24, 9-27. [CrossRef] [PubMed]

2. Abbott, P.V. The periapical space-A dynamic interface. Aust. Endod. J. 2002, 28, 96-107. [CrossRef] 
3. Nair, P.N. Apical periodontitis: A dynamic encounter between root canal infection and host response. Periodontology 2000 1997, 13, 121-148. [CrossRef] [PubMed]

4. Siqueira, J.F., Jr.; Rôças, I.N.; Ricucci, D.; Hülsmann, M. Causes and management of post-treatment apical periodontitis. Br. Dent. J. 2014, 216, 305-312. [CrossRef]

5. Wang, J.; Jiang, Y.; Chen, W.; Zhu, C.; Liang, J. Bacterial flora and extraradicular biofilm associated with the apical segment of teeth with post-treatment apical periodontitis. J. Endod. 2012, 38, 954-959. [CrossRef] [PubMed]

6. Ricucci, D.; Candeiro, G.T.; Bugea, C.; Siqueira, J.F., Jr. Complex Apical Intraradicular Infection and Extraradicular Mineralized Biofilms as the Cause of Wet Canals and Treatment Failure: Report of 2 Cases. J. Endod. 2016, 42, 509-515. [CrossRef] [PubMed]

7. Nair, P.N. Pathogenesis of apical periodontitis and the causes of endodontic failures. Crit. Rev. Oral Biol. Med. 2004, 15, 348-381. [CrossRef] [PubMed]

8. Karamifar, K.; Tondari, A.; Saghiri, M.A. Endodontic Periapical Lesion: An Overview on the Etiology, Diagnosis and Current Treatment Modalities. Eur. Endod. J. 2020, 5, 54-67. [CrossRef] [PubMed]

9. Cekici, A.; Kantarci, A.; Hasturk, H.; Van Dyke, T.E. Inflammatory and immune pathways in the pathogenesis of periodontal disease. Periodontology 2000 2014, 64, 57-80. [CrossRef]

10. Noguchi, N.; Noiri, Y.; Narimatsu, M.; Ebisu, S. Identification and localization of extraradicular biofilm-forming bacteria associated with refractory endodontic pathogens. Appl. Environ. Microbiol. 2005, 71, 8738-8743. [CrossRef]

11. Del Fabbro, M.; Corbella, S.; Sequeira-Byron, P.; Tsesis, I.; Rosen, E.; Lolato, A.; Taschieri, S. Endodontic procedures for retreatment of periapical lesions. Cochrane Database Syst Rev. 2016, 10, CD005511. [CrossRef]

12. Alghamdi, F.; Alhaddad, A.J.; Abuzinadah, S. Healing of Periapical Lesions After Surgical Endodontic Retreatment: A Systematic Review. Cureus 2020, 12, e6916. [CrossRef] [PubMed]

13. Uppada, U.K.; Kalakonda, B.; Koppolu, P.; Varma, N.; Palakurthy, K.; Manchikanti, V.; Prasad, S.; Samar, S.; Swapna, L.A. Combination of hydroxyapatite, platelet rich fibrin and amnion membrane as a novel therapeutic option in regenerative periapical endodontic surgery: Case series. Int. J. Surg. Case Rep. 2017, 37, 139-144. [CrossRef]

14. Restrepo-Restrepo, F.A.; Cañas-Jiménez, S.J.; Romero-Albarracín, R.D.; Villa-Machado, P.A.; Pérez-Cano, M.I.; Tobón-Arroyave, S.I. Prognosis of root canal treatment in teeth with preoperative apical periodontitis: A study with cone-beam computed tomography and digital periapical radiography. Int. Endod. J. 2019, 52, 1533-1546. [CrossRef] [PubMed]

15. Metin, R.; Tatli, U.; Evlice, B. Effects of low-level laser therapy on soft and hard tissue healing after endodontic surgery. Lasers Med. Sci. 2018, 33, 1699-1706. [CrossRef] [PubMed]

16. Yadav, S.; Nawal, R.R.; Talwar, S.; Verma, M. Low-level laser therapy for management of large periapical lesions associated with open apex cases. Indian J. Dent. Res. 2020, 31, 334-336. [CrossRef]

17. Kitchens, J.A.; Schwartz, S.A.; Schindler, W.G.; Hargreaves, K.M. Iontophoresis significantly increases the trans-dentinal delivery of osteoprotegerin, alendronate, and calcitonin. J. Endod. 2007, 33, 1208-1211. [CrossRef]

18. Lietz-Kijak, D.; Kijak, E.; Śliwiński, Z.; Opalko, K. The use of physiotherapy in the regeneration of periapical bone structures of the teeth, prepared to load the prosthetic. Postepy. Hig. Med. Dosw. 2013, 67, 643-647. [CrossRef]

19. Del Fabbro, M.; Bortolinm, M.; Taschieri, S. Is autologous platelet concentrate beneficial for post-extraction socket healing? A systematic review. Int. J. Oral Maxillofac. Surg. 2011, 40, 891-900. [CrossRef]

20. Panda, S.; Doraiswamy, J.; Malaiappan, S.; Varghese, S.S.; Del Fabbro, M. Additive effect of autologous platelet concentrates in treatment of intrabony defects: A systematic review and meta-analysis. J. Investig. Clin. Dent. 2016, 7, 13-26. [CrossRef]

21. Gremmel, T.; Frelinger, A.L., 3rd; Michelson, A.D. Platelet Physiology. Semin. Thromb. Hemost. 2016, 42, 191-204. [CrossRef] [PubMed]

22. King, S.M.; Reed, G.L. Development of platelet secretory granules. Semin. Cell Dev. Biol. 2002, 13, 293-302. [CrossRef]

23. Dohan, D.M.; Choukroun, J.; Diss, A.; Dohan, S.L.; Dohan, A.J.; Mouhyi, J.; Gogly, B. Platelet-rich fibrin (PRF): A secondgeneration platelet concentrate. Part I: Technological concepts and evolution. Oral Surg. Oral Med. Oral Pathol. Oral Radiol. Endod. 2006, 101, e37-e44. [CrossRef]

24. Kao, R.T.; Murakami, S.; Beirne, O.R. The use of biologic mediators and tissue engineering in dentistry. Periodontology 2000 2009, 50, 127-153. [CrossRef] [PubMed]

25. Choukroun, J.; Diss, A.; Simonpieri, A.; Girard, M.O.; Schoeffler, C.; Dohan, S.L.; Dohan, A.J.; Mouhyi, J.; Dohan, D.M. Platelet-rich fibrin (PRF): A second-generation platelet concentrate. Part V: Histologic evaluations of PRF effects on bone allograft maturation in sinus lift. Oral Surg. Oral Med. Oral Pathol. Oral Radiol. Endod. 2006, 101, 299-303. [CrossRef]

26. Handal, T.; Caugant, D.A.; Olsen, I.; Sunde, P.T. Bacterial diversity in persistent periapical lesions on root-filled teeth. J. Oral Microbiol. 2009, 1, 1946. [CrossRef]

27. Eriksen, H.M.; Kirkevang, L.-L.; Petersson, K. Endodontic epidemiology and treatment outcome: General considerations. Endod. Top. 2002, 2, 1-9. [CrossRef]

28. Colić, M.; Gazivoda, D.; Vucević, D.; Vasilijić, S.; Rudolf, R.; Lukić, A. Proinflammatory and immunoregulatory mechanisms in periapical lesions. Mol. Immunol. 2009, 47, 101-113. [CrossRef] [PubMed]

29. Dessaune Neto, N.; Porpino, M.T.M.; Antunes, H.D.S.; Rodrigues, R.C.V.; Perez, A.R.; Pires, F.R.; Siqueira, J.F., Jr.; Armada, L. Pro-inflammatory and anti-inflammatory cytokine expression in post-treatment apical periodontitis. J. Appl. Oral Sci. 2018, 26, e20170455. [CrossRef] 
30. Gazivoda, D.; Dzopalic, T.; Bozic, B.; Tatomirovic, Z.; Brkic, Z.; Colic, M. Production of proinflammatory and immunoregulatory cytokines by inflammatory cells from periapical lesions in culture. J. Oral Pathol. Med. 2009, 38, 605-611. [CrossRef]

31. Jakovljevic, A.; Knezevic, A.; Karalic, D.; Soldatovic, I.; Popovic, B.; Milasin, J.; Andric, M. Pro-inflammatory cytokine levels in human apical periodontitis: Correlation with clinical and histological findings. Aust. Endod. J. 2015, 41, 72-77. [CrossRef] [PubMed]

32. De Carvalho Fraga, C.A.; Alves, L.R.; de Sousa, A.A.; de Jesus, S.F.; Vilela, D.N.; Pereira, C.S.; Batista Domingos, P.L.; Viana, A.G.; Jham, B.C.; Batista de Paula, A.M.; et al. Th1 and Th2-like protein balance in human inflammatory radicular cysts and periapical granulomas. J. Endod. 2013, 39, 453-455. [CrossRef] [PubMed]

33. Walker, K.F.; Lappin, D.F.; Takahashi, K.; Hope, J.; Macdonald, D.G.; Kinane, D.F. Cytokine expression in periapical granulation tissue as assessed by immunohistochemistry. Eur. J. Oral Sci. 2000, 108, 195-201. [CrossRef] [PubMed]

34. Guo, C.; Yang, X.G.; Wang, F.; Ma, X.Y. IL-1 $\alpha$ induces apoptosis and inhibits the osteoblast differentiation of MC3T3-E1 cells through the JNK and p38 MAPK pathways. Int. J. Mol. Med. 2016, 38, 319-327. [CrossRef] [PubMed]

35. Matsuzaki, E.; Anan, H.; Matsumoto, N.; Hatakeyama, J.; Minakami, M.; Izumi, T. Immunopathology of Apical Periodontitis and Refractory Cases. J. Tissue Sci. Eng. 2016, 7, 184. [CrossRef]

36. Garlet, G.P.; Aranha, A.M.F.; Silveira, E.M.; Vieira, A.E.; Queiroz-Junior, C.M.; Madeira, M.F.M.; Fukada, S.Y.; Silva, T.A. The Role of Chemokines and Cytokines in the Pathogenesis of Periodontal and Periapical Lesions: Current Concepts. In Inflammation, Chronic Diseases and Cancer-Cell and Molecular Biology, Immunology and Clinical Bases, 1st ed.; Khatami, M., Ed.; IntechOpen: London, UK, 2012; Volume 1, pp. 219-241. [CrossRef]

37. Braz-Silva, P.H.; Bergamini, M.L.; Mardegan, A.P.; De Rosa, C.S.; Hasseus, B.; Jonasson, P. Inflammatory profile of chronic apical periodontitis: A literature review. Acta Odontol. Scand. 2019, 77, 173-180. [CrossRef] [PubMed]

38. Graunaite, I.; Lodiene, G.; Maciulskiene, V. Pathogenesis of apical periodontitis: A literature review. J. Oral Maxillofac. Res. 2012, 2, e1. [CrossRef] [PubMed]

39. Cheng, R.; Wu, Z.; Li, M.; Shao, M.; Hu, T. Interleukin-1 $\beta$ is a potential therapeutic target for periodontitis: A narrative review. Int. J. Oral Sci. 2020, 12, 2. [CrossRef] [PubMed]

40. Kaneko, N.; Kurata, M.; Yamamoto, T.; Morikawa, S.; Masumoto, J. The role of interleukin-1 in general pathology. Inflamm. Regen. 2019, 39, 12. [CrossRef]

41. Yamada, A.; Takami, M.; Kawawa, T.; Yasuhara, R.; Zhao, B.; Mochizuki, A.; Miyamoto, Y.; Eto, T.; Yasuda, H.; Nakamichi, Y.; et al. Interleukin-4 inhibition of osteoclast differentiation is stronger than that of interleukin-13 and they are equivalent for induction of osteoprotegerin production from osteoblasts. Immunology 2007, 120, 573-579. [CrossRef]

42. AlShwaimi, E.; Berggreen, E.; Furusho, H.; Rossall, J.C.; Dobeck, J.; Yoganathan, S.; Stashenko, P.; Sasaki, H. IL-17 receptor A signaling is protective in infection-stimulated periapical bone destruction. J. Immunol. 2013, 191, 1785-1791. [CrossRef] [PubMed]

43. Fettelschoss, A.; Kistowska, M.; LeibundGut-Landmann, S.; Beer, H.D.; Johansen, P.; Senti, G.; Contassot, E.; Bachmann, M.F.; French, L.E.; Oxenius, A.; et al. Inflammasome activation and IL-1 $\beta$ target IL- $1 \alpha$ for secretion as opposed to surface expression. Proc. Natl. Acad. Sci. USA 2011, 108, 18055-18060. [CrossRef] [PubMed]

44. Dai, S.M.; Nishioka, K.; Yudoh, K. Interleukin (IL) 18 stimulates osteoclast formation through synovial T cells in rheumatoid arthritis: Comparison with IL1 beta and tumour necrosis factor alpha. Ann. Rheum. Dis. 2004, 63, 1379-1386. [CrossRef] [PubMed]

45. Zhang, Q.; Chen, B.; Yan, F.; Guo, J.; Zhu, X.; Ma, S.; Yang, W. Interleukin-10 inhibits bone resorption: A potential therapeutic strategy in periodontitis and other bone loss diseases. Biomed Res. Int. 2014, 2014, 284836. [CrossRef] [PubMed]

46. Bendre, M.S.; Montague, D.C.; Peery, T.; Akel, N.S.; Gaddy, D.; Suva, L.J. Interleukin-8 stimulation of osteoclastogenesis and bone resorption is a mechanism for the increased osteolysis of metastatic bone disease. Bone 2003, 33, 28-37. [CrossRef]

47. Ruef, N.; Dolder, S.; Aeberli, D.; Seitz, M.; Balani, D.; Hofstetter, W. Granulocyte-macrophage colony-stimulating factor-dependent CD11c-positive cells differentiate into active osteoclasts. Bone 2017, 97, 267-277. [CrossRef] [PubMed]

48. Lee, M.S.; Kim, H.S.; Yeon, J.T.; Choi, S.W.; Chun, C.H.; Kwak, H.B.; Oh, J. GM-CSF regulates fusion of mononuclear osteoclasts into bone-resorbing osteoclasts by activating the Ras/ERK pathway. J. Immunol. 2009, 183, 3390-3399. [CrossRef]

49. Zhao, B. TNF and Bone Remodeling. Curr. Osteoporos. Rep. 2017, 15, 126-134. [CrossRef]

50. Scheffler, J.M.; Grahnemo, L.; Engdahl, C.; Drevinge, C.; Gustafsson, K.L.; Corciulo, C.; Lawenius, L.; Iwakura, Y.; Sjögren, K.; Lagerquist, M.K.; et al. Interleukin 17A: A Janus-faced regulator of osteoporosis. Sci. Rep. 2020, 10, 5692. [CrossRef]

51. He, L.; Hannon, G.J. MicroRNAs: Small RNAs with a big role in gene regulation. Nat. Rev. Genet. 2004, 5, 522-531. [CrossRef]

52. Kaeuferle, T.; Bartel, S.; Dehmel, S.; Krauss-Etschmann, S. MicroRNA methodology: Advances in miRNA technologies. Methods Mol. Biol. 2014, 1169, 121-130. [CrossRef]

53. Sontheimer, E.J. Assembly and function of RNA silencing complexes. Nat. Rev. Mol. Cell Biol. 2005, 6, 127-138. [CrossRef] [PubMed]

54. Gu, S.; Jin, L.; Zhang, F.; Sarnow, P.; Kay, M.A. Biological basis for restriction of microRNA targets to the $3^{\prime}$ untranslated region in mammalian mRNAs. Nat. Struct. Mol. Biol. 2009, 16, 144-150. [CrossRef]

55. Bracht, J.; Hunter, S.; Eachus, R.; Weeks, P.; Pasquinelli, A.E. Trans-splicing and polyadenylation of let-7 microRNA primary transcripts. RNA 2004, 10, 1586-1594. [CrossRef] [PubMed]

56. Macfarlane, L.A.; Murphy, P.R. MicroRNA: Biogenesis, Function and Role in Cancer. Curr Genom. 2010, 11, 537-561. [CrossRef] [PubMed] 
57. Shapiro, J.S.; Langlois, R.A.; Pham, A.M.; Tenoever, B.R. Evidence for a cytoplasmic microprocessor of pri-miRNAs. RNA 2012, 18, 1338-1346. [CrossRef] [PubMed]

58. Bushati, N.; Cohen, S.M. microRNA functions. Annu. Rev. Cell Dev. Biol. 2007, 23, 175-205. [CrossRef]

59. Baek, D.; Villén, J.; Shin, C.; Camargo, F.D.; Gygi, S.P.; Bartel, D.P. The impact of microRNAs on protein output. Nature 2008, 455, 64-71. [CrossRef]

60. Dave, R.S.; Khalili, K. Morphine treatment of human monocyte-derived macrophages induces differential miRNA and protein expression: Impact on inflammation and oxidative stress in the central nervous system. J. Cell Biochem. 2010, 110, 834-845. [CrossRef]

61. Chan, L.T.; Zhong, S.; Naqvi, A.R.; Self-Fordham, J.; Nares, S.; Bair, E.; Khan, A.A. MicroRNAs: New insights into the pathogenesis of endodontic periapical disease. J. Endod. 2013, 39, 1498-1503. [CrossRef]

62. Gao, B.; Zheng, L. microRNA Expression in Rat Apical Periodontitis Bone Lesion. Bone Res. 2013, 1, 170-185. [CrossRef] [PubMed]

63. Henriksen, K.; Sørensen, M.G.; Nielsen, R.H.; Gram, J.; Schaller, S.; Dziegiel, M.H.; Everts, V.; Bollerslev, J.; Karsdal, M.A. Degradation of the organic phase of bone by osteoclasts: A secondary role for lysosomal acidification. J. Bone Miner. Res. 2006, 21, 58-66. [CrossRef] [PubMed]

64. Hu, C.H.; Sui, B.D.; Du, F.Y.; Shuai, Y.; Zheng, C.X.; Zhao, P.; Yu, X.R.; Jin, Y. miR-21 deficiency inhibits osteoclast function and prevents bone loss in mice. Sci. Rep. 2017, 7, 43191. [CrossRef]

65. Baćević, M.; Brković, B.; Lambert, F.; Djukić, L.; Petrović, N.; Roganović, J. Leukocyte- and platelet-rich fibrin as graft material improves microRNA-21 expression and decreases oxidative stress in the calvarial defects of diabetic rabbits. Arch. Oral Biol. 2019, 102, 231-237. [CrossRef] [PubMed]

66. Wang, T.; Feng, Y.; Sun, H.; Zhang, L.; Hao, L.; Shi, C.; Wang, J.; Li, R.; Ran, X.; Su, Y.; et al. miR-21 regulates skin wound healing by targeting multiple aspects of the healing process. Am. J. Pathol. 2012, 181, 1911-1920. [CrossRef] [PubMed]

67. Chien, H.Y.; Lee, T.P.; Chen, C.Y.; Chiu, Y.H.; Lin, Y.C.; Lee, L.S.; Li, W.C. Circulating microRNA as a diagnostic marker in populations with type 2 diabetes mellitus and diabetic complications. J. Chin. Med. Assoc. 2015, 78, 204-211. [CrossRef] [PubMed]

68. Yue, J.; Song, D.; Lu, W.; Lu, Y.; Zhou, W.; Tan, X.; Zhang, L.; Huang, D. Expression Profiles of Inflammation-associated microRNAs in Periapical Lesions and Human Periodontal Ligament Fibroblasts Inflammation. J. Endod. 2016, 42, 1773-1778. [CrossRef]

69. Wang, X.; Sun, H.; Liu, H.; Ma, L.; Jiang, C.; Liao, H.; Xu, S.; Xiang, J.; Cao, Z. MicroRNA-181b-5p modulates tumor necrosis factor- $\alpha$-induced inflammatory responses by targeting interleukin-6 in cementoblasts. J. Cell. Physiol. 2019, 234, 22719-22730. [CrossRef]

70. Shen, Z.; Silva, R.M. MicroRNAs: Emerging players in apical periodontitis. J. Appl. Oral Sci. 2021, 29, e20201058. [CrossRef]

71. Lin, Y.; Xing, Q.; Qin, W.; de Melo, M.A.S.; Zou, R.; Xu, M.; Zhang, X.; Xu, H.H.K.; Lin, Z. Decreased Expression of Semaphorin3A/Neuropilin-1 Signaling Axis in Apical Periodontitis. Biomed Res. Int. 2017, 2017, 8724503. [CrossRef] [PubMed]

72. Shen, Z.; Wichnieski, C.; Carneiro, E.; Garlet, G.P.; Letra, A.; Silva, R.M. Expression Profiling and Functional Characterization of MicroRNAs in Apical Periodontitis. J. Endod. 2021, 47, 263-271. [CrossRef]

73. Mohammadi, Z.; Dummer, P.M. Properties and applications of calcium hydroxide in endodontics and dental traumatology. Int. Endod. J. 2011, 44, 697-730. [CrossRef] [PubMed]

74. Sathorn, C.; Parashos, P.; Messer, H. Antibacterial efficacy of calcium hydroxide intracanal dressing: A systematic review and meta-analysis. Int. Endod. J. 2007, 40, 2-10. [CrossRef] [PubMed]

75. Peters, L.B.; Wesselink, P.R. Periapical healing of endodontically treated teeth in one and two visits obturated in the presence or absence of detectable microorganisms. Int. Endod. J. 2002, 35, 660-667. [CrossRef]

76. Haapasalo, M.; Shen, Y.; Wang, Z.; Gao, Y. Irrigation in endodontics. Br. Dent. J. 2014, 216, 299-303. [CrossRef] [PubMed]

77. Rodrigues, R.C.; Antunes, H.S.; Neves, M.A.; Siqueira, J.F., Jr.; Rôças, I.N. Infection Control in Retreatment Cases: In Vivo Antibacterial Effects of 2 Instrumentation Systems. J. Endod. 2015, 41, 1600-1605. [CrossRef] [PubMed]

78. Nagendrababu, V.; Jayaraman, J.; Suresh, A.; Kalyanasundaram, S.; Neelakantan, P. Effectiveness of ultrasonically activated irrigation on root canal disinfection: A systematic review of in vitro studies. Clin Oral Investig. 2018, 22, 655-670. [CrossRef]

79. Siqueira, J.F., Jr.; Rôças, I.N.; Favieri, A.; Lima, K.C. Chemomechanical reduction of the bacterial population in the root canal after instrumentation and irrigation with 1\%,2.5\%, and 5.25\% sodium hypochlorite. J. Endod. 2000, 26, 331-334. [CrossRef] [PubMed]

80. Orstavik, D. Time-course and risk analyses of the development and healing of chronic apical periodontitis in man. Int. Endod. J. 1996, 29, 150-155. [CrossRef]

81. Mokbel, N.; Kassir, A.R.; Naaman, N.; Megarbane, J.M. Root Resection and Hemisection Revisited. Part I: A Systematic Review. Int. J. Periodontics Restor. Dent. 2019, 39, e11-e31. [CrossRef] [PubMed]

82. Jadun, S.; Monaghan, L.; Darcey, J. Endodontic microsurgery. Part two: Armamentarium and technique. Br. Dent. J. 2019, 227, 101-111. [CrossRef] [PubMed]

83. Von Arx, T. Apical surgery: A review of current techniques and outcome. Saudi Dent. J. 2011, 23, 9-15. [CrossRef] [PubMed]

84. Floratos, S.; Kim, S. Modern Endodontic Microsurgery Concepts: A Clinical Update. Dent. Clin. N. Am. 2017, 61, 81-91. [CrossRef]

85. Hawkins, T.K.; Wealleans, J.A.; Pratt, A.M.; Ray, J.J. Targeted endodontic microsurgery and endodontic microsurgery: A surgical simulation comparison. Int. Endod. J. 2020, 53, 715-722. [CrossRef]

86. Pinto, D.; Marques, A.; Pereira, J.F.; Palma, P.J.; Santos, J.M. Long-Term Prognosis of Endodontic Microsurgery-A Systematic Review and Meta-Analysis. Medicina 2020, 56, 447. [CrossRef] 
87. Sebring, D.; Kvist, T.; Derks, J. Indications for Extraction before Implant Therapy: Focus on Endodontic Status. J. Endod. 2019, 45, 532-537. [CrossRef] [PubMed]

88. Palma, P.J.; Marques, J.A.; Casau, M.; Santos, A.; Caramelo, F.; Falacho, R.I.; Santos, J.M. Evaluation of Root-End Preparation with Two Different Endodontic Microsurgery Ultrasonic Tips. Biomedicines 2020, 8, 383. [CrossRef] [PubMed]

89. Craddock, H.L.; Youngson, C.C.; Manogue, M.; Blance, A. Occlusal changes following posterior tooth loss in adults. Part 1: A study of clinical parameters associated with the extent and type of supraeruption in unopposed posterior teeth. J. Prosthodont. 2007, 16, 485-494. [CrossRef]

90. Craddock, H.L.; Youngson, C.C.; Manogue, M.; Blance, A. Occlusal changes following posterior tooth loss in adults. Part 2. Clinical parameters associated with movement of teeth adjacent to the site of posterior tooth loss. J. Prosthodont. 2007, 16, 495-501. [CrossRef] [PubMed]

91. Craddock, H.L. Occlusal changes following posterior tooth loss in adults. Part 3. A study of clinical parameters associated with the presence of occlusal interferences following posterior tooth loss. J. Prosthodont. 2008, 17, 25-30. [CrossRef] [PubMed]

92. Thon, J.N.; Italiano, J.E. Platelet formation. Semin. Hematol. 2010, 47, 220-226. [CrossRef] [PubMed]

93. Cognasse, F.; Hamzeh, H.; Chavarin, P.; Acquart, S.; Genin, C.; Garraud, O. Evidence of Toll-like receptor molecules on human platelets. Immunol. Cell Biol. 2005, 83, 196-198. [CrossRef]

94. Ross, R.; Glomset, J.; Kariya, B.; Harker, L. A platelet-dependent serum factor that stimulates the proliferation of arterial smooth muscle cells in vitro. Proc. Natl. Acad. Sci. USA 1974, 71, 1207-1210. [CrossRef] [PubMed]

95. Dohan Ehrenfest, D.M.; Rasmusson, L.; Albrektsson, T. Classification of platelet concentrates: From pure platelet-rich plasma (P-PRP) to leucocyte- and platelet-rich fibrin (L-PRF). Trends Biotechnol. 2009, 27, 158-167. [CrossRef] [PubMed]

96. Dohan Ehrenfest, D.M.; Del Corso, M.; Diss, A.; Mouhyi, J.; Charrier, J.B. Three-dimensional architecture and cell composition of a Choukroun's platelet-rich fibrin clot and membrane. J. Periodontol. 2010, 81, 546-555. [CrossRef] [PubMed]

97. Dohan Ehrenfest, D.M.; Andia, I.; Zumstein, M.A.; Zhang, C.Q.; Pinto, N.R.; Bielecki, T. Classification of platelet concentrates (Platelet-Rich Plasma-PRP, Platelet-Rich Fibrin-PRF) for topical and infiltrative use in orthopedic and sports medicine: Current consensus, clinical implications and perspectives. Muscles Ligaments Tendons J. 2014, 4, 3-9. [CrossRef] [PubMed]

98. Fujioka-Kobayashi, M.; Miron, R.J.; Hernandez, M.; Kandalam, U.; Zhang, Y.; Choukroun, J. Optimized Platelet-Rich Fibrin With the Low-Speed Concept: Growth Factor Release, Biocompatibility, and Cellular Response. J. Periodontol. 2017, 88, 112-121. [CrossRef]

99. Miron, R.J.; Xu, H.; Chai, J.; Wang, J.; Zheng, S.; Feng, M.; Zhang, X.; Wei, Y.; Chen, Y.; Mourão, C.F.A.B.; et al. Comparison of platelet-rich fibrin (PRF) produced using 3 commercially available centrifuges at both high ( 700 g) and low ( 200 g) relative centrifugation forces. Clin. Oral Investig. 2020, 24, 1171-1182. [CrossRef]

100. Ghanaati, S.; Booms, P.; Orlowska, A.; Kubesch, A.; Lorenz, J.; Rutkowski, J.; Landes, C.; Sader, R.; Kirkpatrick, C.; Choukroun, J. Advanced platelet-rich fibrin: A new concept for cell-based tissue engineering by means of inflammatory cells. J. Oral Implantol. 2014, 40, 679-689. [CrossRef]

101. Kobayashi, E.; Flückiger, L.; Fujioka-Kobayashi, M.; Sawada, K.; Sculean, A.; Schaller, B.; Miron, R.J. Comparative release of growth factors from PRP, PRF, and advanced-PRF. Clin. Oral Investig. 2016, 20, 2353-2360. [CrossRef]

102. Canellas, J.V.D.S.; Medeiros, P.J.D.; Figueredo, C.M.D.S.; Fischer, R.G.; Ritto, F.G. Platelet-rich fibrin in oral surgical procedures: A systematic review and meta-analysis. Int. J. Oral Maxillofac. Surg. 2019, 48, 395-414. [CrossRef] [PubMed]

103. Wang, X.; Zhang, Y.; Choukroun, J.; Ghanaati, S.; Miron, R.J. Effects of an injectable platelet-rich fibrin on osteoblast behavior and bone tissue formation in comparison to platelet-rich plasma. Platelets 2018, 29, 48-55. [CrossRef]

104. Hu, K.; Olsen, B.R. The roles of vascular endothelial growth factor in bone repair and regeneration. Bone 2016, 91, 30-38. [CrossRef]

105. Moojen, D.J.; Everts, P.A.; Schure, R.M.; Overdevest, E.P.; van Zundert, A.; Knape, J.T.; Castelein, R.M.; Creemers, L.B.; Dhert, W.J. Antimicrobial activity of platelet-leukocyte gel against Staphylococcus aureus. J. Orthop. Res. 2008, 26, 404-410. [CrossRef]

106. Dohan, D.M.; Choukroun, J.; Diss, A.; Dohan, S.L.; Dohan, A.J.; Mouhyi, J.; Gogly, B. Platelet-rich fibrin (PRF): A secondgeneration platelet concentrate. Part III: Leucocyte activation: A new feature for platelet concentrates? Oral Surg. Oral Med. Oral Pathol. Oral Radiol. Endod. 2006, 101, e51-e55. [CrossRef]

107. Kour, P.; Pudakalkatti, P.S.; Vas, A.M.; Das, S.; Padmanabhan, S. Comparative Evaluation of Antimicrobial Efficacy of Plateletrich Plasma, Platelet-rich Fibrin, and Injectable Platelet-rich Fibrin on the Standard Strains of Porphyromonas gingivalis and Aggregatibacter actinomycetemcomitans. Contemp. Clin. Dent. 2018, 9 (Suppl. S2), S325-S330. [CrossRef]

108. Everts, P.; Onishi, K.; Jayaram, P.; Lana, J.F.; Mautner, K. Platelet-Rich Plasma: New Performance Understandings and Therapeutic Considerations in 2020. Int. J. Mol. Sci. 2020, 21, 7794. [CrossRef] [PubMed]

109. Xu, J.; Gou, L.; Zhang, P.; Li, H.; Qiu, S. Platelet-rich plasma and regenerative dentistry. Aust. Dent. J. 2020, 65, 131-142. [CrossRef]

110. Borie, E.; Oliví, D.G.; Orsi, I.A.; Garlet, K.; Weber, B.; Beltrán, V.; Fuentes, R. Platelet-rich fibrin application in dentistry: A literature review. Int. J. Clin. Exp. Med. 2015, 8, 7922-7929.

111. Miron, R.J.; Zucchelli, G.; Pikos, M.A.; Salama, M.; Lee, S.; Guillemette, V.; Fujioka-Kobayashi, M.; Bishara, M.; Zhang, Y.; Wang, H.L.; et al. Use of platelet-rich fibrin in regenerative dentistry: A systematic review. Clin. Oral Investig. 2017, 21, $1913-1927$. [CrossRef] [PubMed] 
112. Liu, Y.; Sun, X.; Yu, J.; Wang, J.; Zhai, P.; Chen, S.; Liu, M.; Zhou, Y. Platelet-Rich Fibrin as a Bone Graft Material in Oral and Maxillofacial Bone Regeneration: Classification and Summary for Better Application. Biomed Res. Int. 2019, $2019,3295756$. [CrossRef]

113. Fan, Y.; Perez, K.; Dym, H. Clinical Uses of Platelet-Rich Fibrin in Oral and Maxillofacial Surgery. Dent. Clin. N. Am. 2020, 64, 291-303. [CrossRef] [PubMed]

114. Metlerska, J.; Fagogeni, I.; Nowicka, A. Efficacy of Autologous Platelet Concentrates in Regenerative Endodontic Treatment: A Systematic Review of Human Studies. J. Endod. 2019, 45, 20-30.e1. [CrossRef]

115. Kim, S.G.; Malek, M.; Sigurdsson, A.; Lin, L.M.; Kahler, B. Regenerative endodontics: A comprehensive review. Int. Endod. J. 2018, 51, 1367-1388. [CrossRef] [PubMed]

116. Qin, Y.; Guan, J.; Zhang, C. Mesenchymal stem cells: Mechanisms and role in bone regeneration. Postgrad. Med. J. 2014, 90, 643-647. [CrossRef]

117. Yagi, H.; Soto-Gutierrez, A.; Parekkadan, B.; Kitagawa, Y.; Tompkins, R.G.; Kobayashi, N.; Yarmush, M.L. Mesenchymal stem cells: Mechanisms of immunomodulation and homing. Cell Transplant. 2010, 19, 667-679. [CrossRef] [PubMed]

118. Maria, O.M.; Khosravi, R.; Mezey, E.; Tran, S.D. Cells from bone marrow that evolve into oral tissues and their clinical applications. Oral Dis. 2007, 13, 11-16. [CrossRef]

119. Tian, S.; Wang, J.; Dong, F.; Du, N.; Li, W.; Song, P.; Liu, Y. Concentrated Growth Factor Promotes Dental Pulp Cells Proliferation and Mineralization and Facilitates Recovery of Dental Pulp Tissue. Med. Sci. Monit. 2019, 25, 10016-10028. [CrossRef]

120. Hu, L.; Zhao, B.; Gao, Z.; Xu, J.; Fan, Z.; Zhang, C.; Wang, J.; Wang, S. Regeneration characteristics of different dental derived stem cell sheets. J. Oral Rehabil. 2020, 47 (Suppl. S1), 66-72. [CrossRef]

121. Salamanna, F.; Del Piccolo, N.; Sartori, M.; Giavaresi, G.; Martini, L.; Di Sante, G.; Stagni, C.; Dallari, D.; Fini, M. Effects of Autologous Bone Marrow Mesenchymal Stem Cells and Platelet-Rich Plasma on Bone Regeneration and Osseointegration of a Hydroxyapatite-Coated Titanium Implant. Coatings 2021, 11, 840. [CrossRef]

122. Dohan Ehrenfest, D.M.; Doglioli, P.; de Peppo, G.M.; Del Corso, M.; Charrier, J.B. Choukroun's platelet-rich fibrin (PRF) stimulates in vitro proliferation and differentiation of human oral bone mesenchymal stem cell in a dose-dependent way. Arch. Oral Biol. 2010, 55, 185-194. [CrossRef]

123. Sequeira, D.B.; Oliveira, A.R.; Seabra, C.M.; Palma, P.J.; Ramos, C.; Figueiredo, M.H.; Santos, A.C.; Cardoso, A.L.; Peça, J.; Santos, J.M. Regeneration of pulp-dentin complex using human stem cells of the apical papilla: In vivo interaction with two bioactive materials. Clin. Oral Investig. 2021, 25, 5317-5329. [CrossRef]

124. Xu, F.; Qiao, L.; Zhao, Y.; Chen, W.; Hong, S.; Pan, J.; Jiang, B. The potential application of concentrated growth factor in pulp regeneration: An in vitro and in vivo study. Stem Cell Res. Ther. 2019, 10, 134. [CrossRef] [PubMed]

125. Rochira, A.; Siculella, L.; Damiano, F.; Palermo, A.; Ferrante, F.; Carluccio, M.A.; Calabriso, N.; Giannotti, L.; Stanca, E. Concentrated Growth Factors (CGF) Induce Osteogenic Differentiation in Human Bone Marrow Stem Cells. Biology 2020, 9, 370. [CrossRef] [PubMed]

126. Zhang, Z.; Li, X.; Zhao, J.; Jia, W.; Wang, Z. Effect of autogenous growth factors released from platelet concentrates on the osteogenic differentiation of periodontal ligament fibroblasts: A comparative study. Peer] 2019, 7, e7984. [CrossRef] [PubMed]

127. Li, Z.; Liu, L.; Wang, L.; Song, D. The effects and potential applications of concentrated growth factor in dentin-pulp complex regeneration. Stem Cell Res. Ther. 2021, 12, 357. [CrossRef] [PubMed]

128. Machut, K.; Zoltowska, A.; Pawlowska, E.; Derwich, M. Plasma Rich in Growth Factors in the Treatment of Endodontic Periapical Lesions in Adult Patients: Case Reports. Int. J. Mol. Sci. 2021, 22, 9458. [CrossRef] [PubMed]

129. Soto-Peñaloza, D.; Peñarrocha-Diago, M.; Cervera-Ballester, J.; Peñarrocha-Diago, M.; Tarazona-Alvarez, B.; Peñarrocha-Oltra, D. Pain and quality of life after endodontic surgery with or without advanced platelet-rich fibrin membrane application: A randomized clinical trial. Clin. Oral Investig. 2020, 24, 1727-1738. [CrossRef]

130. Kavitha, M.; Krishnaveni, R.; Swathi, A.M.; Abubacker, M.H.M. Evaluation of healing by Cone Beam Computed Tomography $(\mathrm{CBCT})$ using Platelet-Rich Plasma (PRP) $+\beta$-Tricalcium Phosphate $(\beta-\mathrm{TCP})$ and Platelet Rich Fibrin $(\mathrm{PRF})+\beta-$ Tricalcium Phosphate $(\beta-\mathrm{TCP})$ in periapical lesions: Case report. Niger J. Clin. Pract. 2020, 23, 1026-1029. [CrossRef] [PubMed]

131. Sureshbabu, N.M.; Ranganath, A.; Jacob, B. Concentrated Growth Factor-Surgical Management of Large Periapical Lesion Using a Novel Platelet Concentrate in Combination with Bone Graft. Ann. Maxillofac. Surg. 2020, 10, 246-250. [CrossRef] [PubMed]

132. Taschieri, S.; Rosano, G.; Weinstein, T.; Bortolin, M.; Del Fabbro, M. Treatment of through-and-through bone lesion using autologous growth factors and xenogeneic bone graft: A case report. Oral Maxillofac. Surg. 2012, 16, 57-64. [CrossRef] [PubMed]

133. Shivashankar, V.Y.; Johns, D.A.; Vidyanath, S.; Sam, G. Combination of platelet rich fibrin, hydroxyapatite and PRF membrane in the management of large inflammatory periapical lesion. J. Conserv. Dent. 2013, 16, 261-264. [CrossRef] [PubMed]

134. Zhao, J.H.; Tsai, C.H.; Chang, Y.C. Management of radicular cysts using platelet-rich fibrin and bioactive glass: A report of two cases. J. Formos. Med. Assoc. 2014, 113, 470-476. [CrossRef] [PubMed]

135. Dudeja, P.G.; Dudeja, K.K.; Garg, A.; Srivastava, D.; Grover, S. Management of a Previously Treated, Calcified, and Dilacerated Maxillary Lateral Incisor: A Combined Nonsurgical/Surgical Approach Assisted by Cone-beam Computed Tomography. J. Endod. 2016, 42, 984-988. [CrossRef]

136. Wadhwa, J.; Gupta, A.; Hans, S. Evaluation of Periapical Healing of Apicomarginal Defect in Mandibular First Molar Treated with Platelet Rich Fibrin: A Case Report. J. Clin. Diagn. Res. 2017, 11, ZD01-ZD03. [CrossRef] 
137. Vidhale, G.; Jain, D.; Jain, S.; Godhane, A.V.; Pawar, G.R. Management of Radicular Cyst Using Platelet-Rich Fibrin \& Iliac Bone Graft-A Case Report. J. Clin. Diagn. Res. 2015, 9, ZD34-ZD36. [CrossRef] [PubMed]

138. Bains, R.; Bains, V.K.; Loomba, K.; Verma, K.; Nasir, A. Management of pulpal floor perforation and grade II Furcation involvement using mineral trioxide aggregate and platelet rich fibrin: A clinical report. Contemp. Clin. Dent. 2012, 3 (Suppl. S2), S223-S227. [CrossRef] [PubMed]

139. Demiralp, B.; Ke $\sqrt{ }$ Beli, H.G.; Muhtarońüullar, M.; Serper, A.; Demiralp, B.; Eratalay, K. Treatment of periapical inflammatory lesion with the combination of platelet-rich plasma and tricalcium phosphate: A case report. J. Endod. 2004, 30, 796-800. [CrossRef] [PubMed]

140. Hiremath, H.; Motiwala, T.; Jain, P.; Kulkarni, S. Use of second-generation platelet concentrate (platelet-rich fibrin) and hydroxyapatite in the management of large periapical inflammatory lesion: A computed tomography scan analysis. Indian J. Dent. Res. 2014, 25, 517-520. [CrossRef] [PubMed]

141. Parikh, B.; Navin, S.; Vaishali, P. A comparative evaluation of healing with a computed tomography scan of bilateral periapical lesions treated with and without the use of platelet-rich plasma. Indian J. Dent. Res. 2011, 22, 497-498. [CrossRef] [PubMed] 